DOI: $10.5800 /$ GT-2020-11-3-0489

\title{
SPECIFIC FEATURES OF STRUCTURE FORMATION DURING THE DEVELOPMENT OF THE LITHOSPHERE OF THE GULF OF ADEN (PHYSICAL MODELING)
}

\author{
E.P. Dubinin ${ }^{\otimes}$, A.L. Grokholsky $(1)$
}

Earth Science Museum, Lomonosov Moscow State University, 1 Leninskie Gori, Moscow 119991, Russia

\begin{abstract}
The study was focused on the tectonic structure features of the Gulf of Aden, which includes three provinces. The western, central and eastern provinces differ in morphostructural segmentation of the spreading ridge of the Gulf of Aden, which took place in different geodynamic regimes of their formation and development. In our study, physical modeling was performed to investigate the segmentation mechanisms of the three parts and the formation of the marginal plateau and the island of Socotra. In experiments, an elastic-plastic plate lying on a liquid base (simulating melt) was subjected to normal or oblique stretchig. Plate sections imitating the continental or oceanic lithosphere in the model had different thicknesses. Various heterogeneities, such as cuts, linear weakened zones (rift heating zones) etc., were set in the plate sections in accordance with natural analogues. The modeling results show that morphostructural segmentation of the spreading axis in the Gulf of Aden depends on the degree of heating and the thickness of the lithosphere, associated with different distances from the Afar plume and local thermal anomalies, spreading obliquity and the existence of structural inhomogeneities with increased lithosphere strength, which are associated in this case with the presence of Mesozoic grabens on the pre-breakup basement. The smaller is the lithosphere thickness, the smaller is the size of the segments. The sharper is the angle, the more pronounced is segmentation.

The study of the connection of the Gulf of Aden continental rift with the rift zone of the Carlsberg ridge suggests that during their development, these rift fractures propagated towards each other. The experiment results show that in case of a «sharp» boundary between blocks that differ in thickness, a shear zone is likely to occur. Such a case is applicable, for example, to the Alula-Fartak fracture zone, or to Owen's fracture zone. With a less 'sharp' boundary, overlapping structures are often formed, such as microplates or microblocks enclosed between two rift fissures. In such case, one microblock then dies, while the other develops into a spreading ridge. Apparently, such a microblock is represented by the marginal plateau and the island of Sokotra. As shown by the modeling, propagation of the two rifts towards each other was important for the formation of the plateau and the island of Socotra. Moreover, a significant role was played by the initial geometry of the rift zones and their initial positioning separate from each other.
\end{abstract}

KEYWORDS: Gulf of Aden; Socotra; rifting; spreading ridge; passive margin; physical modeling; structure formation

FUNDING: The study was financially supported by the Russian Foundation for Basic Research (project 18-05-00378).

\section{RESEARCH ARTICLE}

Correspondence: Evgeny P. Dubinin, edubinin08@rambler.ru
Received: May 22, 2019

Revised: December 14, 2019

Accepted: February 12, 2020

FOR CITATION: Dubinin E.P., Grokholsky A.L., 2020. Specific features of structure formation during the development of the lithosphere of the Gulf of Aden (physical modeling). Geodynamics \& Tectonophysics 11 (3), 522-547. doi:10.5800/GT-2020-11-3-0489 


\title{
ОСОБЕННОСТИ СТРУКТУРООБРАЗОВАНИЯ В ПРОЦЕССЕ РАЗВИТИЯ ЛИТОСФЕРЫ АДЕНСКОГО ЗАЛИВА (ФИЗИЧЕСКОЕ МОДЕЛИРОВАНИЕ)
}

\author{
Е.П. Дубинин, А.Л. Грохольский
}

Музей землеведения Московского государственного университета им. М.В. Ломоносова, 119991, Москва, Ленинские горы, 1, Россия

АНнОТАЦИЯ. Рассмотрены особенности тектонического строения бассейна Аденского залива, включающего три различные провинции: восточную, центральную и западную. Различие в морфоструктурной сегментации спредингового хребта Аденского залива отражает разный геодинамический режим формирования и развития этих провинций.

С помощью физического моделирования исследованы механизмы сегментации зоны спрединга в западной, центральной и восточной части Аденского залива, а также условия формирования краевого плато и о. Сокотра. В экспериментах плита с упругопластическими свойствами, лежащая на жидком основании, подвергалась нормальному или косому растяжению. Участки плиты, имитирующие в модели континентальную или океаническую литосферу, имели разную толщину. В них в соответствии с природными обстановками задавались различные неоднородности: разрезы, линейные ослабленные зоны (зоны прогрева рифта) и др. Результаты экспериментов показали, что характер морфоструктурной сегментации оси спрединга в районе Аденского залива зависит от степени прогретости мантии и толщины литосферы, связанной с разной удаленностью от Афарского плюма и локальными термическими аномалиями, от косости спрединга и существования структурных неоднородностей с повышенной прочностью литосферы, обусловленных в данном случае наличием серии мезозойских грабенов на дораскольном фундаменте. Чем меньше мощность литосферы, тем меньше размеры сегментов; чем острее угол, тем более выражена сегментация. Исследование условий соединения континентального рифта Аденского залива с рифтовой зоной спредингового хребта Карлсберг показало, что, по всей видимости, рифты развивались посредством их продвижения навстречу друг другу. Эксперименты показали, что в случае «резкой» границы между блоками разной толщины, вероятнее всего, возникнет сдвиговая зона. Эта ситуация применима, например, к разлому Алула-Фартак или к разлому Оуэн. В случае менее «резкой» границы часто формируются структуры перекрытия, представляющие собой микроплиты, или микроблоки, заключенные между двумя рифтами, один из которых в дальнейшем отмирает, а другой развивается в спрединговый хребет. Таким микроблоком, видимо, является краевое плато и о. Сокотра. Как показало моделирование, при формировании плато и о. Сокотра важную роль играет встречное продвижение двух рифтов, причем существенное значение имеет первоначальная геометрия рифтовых зон и их разнос относительно друг друга.

КЛЮЧЕВЫЕ СЛОВА: Аденский залив; о. Сокотра; рифтинг; спрединговый хребет; пассивная окраина; физическое моделирование; структурообразование

ФИНАНСИРОВАНИЕ: Работа выполнена при поддержке РФФИ (проект № 18-05-00378).

\section{1. ВВЕДЕНИЕ}

Аденский залив сформировался в результате раскола единого Африкано-Аравийского блока и развития глобальной Восточно-Африканской - КрасноморскоАденской рифтовой системы вследствие субдукции литосферы Тетиса, приведшей к изменению кинематики плит и к началу движения Аравийской плиты относительно Африканской в эоцене [Bellahsen et al., 2013b]. На обоих бортах Аденского залива обнажаются метаморфические породы докембрийского фундамента, несогласно перекрытые юрскими, меловыми, палеоценовыми и эоценовыми отложениями. Со стороны континентов к нему также примыкает серия сопряженных структурных неоднородностей северо-западного простирания в виде грабенов Джиза-Камар - Гвардафуй, Масила - Даррор, Мариб-Балхав - Бербера-Ногад, АшавкСалалах и др., сформированных в результате мезозойского рифтинга и реактивированных в олигоцене [Leroy et al., 2010a, 2010b, 2012] (рис.1). До момента кайнозойского раскола литосферы эти грабены составляли единый рифтогенный бассейн и представляли собой структурные неоднородности с более прочной литосферой на пути развивающегося кайнозойского рифта [Bosworth et al., 2005; d'Acremont etal., 2006]. Это одна из ключевых особенностей региона, которая могла сыграть значительную роль в развитии современной структуры Аденского океанического бассейна.

Еще одной особенностью, существенно повлиявшей на геодинамику и тектоническое развитие бассейна Аденского залива, явилась активизация Афарского плюма и связанная с ним магматическая деятельность. Начало деятельности Афарского плюма относят к 45 млн лет назад, хотя временем его активизации считается рубеж около 30 млн лет назад, сразу после начала рифтинга в Аденском заливе 34 млн лет назад. Трахиты, найденные в основании разреза вулканитов, имеют возраст 
около 31 млн лет, самые древние риолиты - 30 млн лет [Bellahsen et al., 2013b]. Возрастание вулканической активности произошло 25-20 млн лет назад и маркировалось игнимбритами, а также внедрением щелочных и субщелочных гранитов по границам Афарской депрессии. Внутри нее были обнаружены излияния базальтов с возрастом 22-14 млн лет, а также риолиты, игнимбриты и базальты с возрастом 14-10 млн лет. Базальтовый вулканизм вновь активизировался 8.03.5 млн лет назад. Литосфера в области Афар испытала за этот период сильное растяжение. А за последний миллион лет здесь происходят извержения щелочных и субщелочных кислых пород и базальтов из трещинных вулканов [Bosworth et al., 2012].

Современный Аденский залив вытянут субширотно от $42^{\circ} 37^{\prime}$ до 51²16 в.д. Длина залива - 890 км, ширина - до 300 км в восточной части (рис. 2, а). На западе залив ограничен побережьем Африканского континента, куда он вдается заливом Таджура. Восточной границей считается крайняя восточная точка Африки мыс Гвардафуй. В настоящей работе мы рассматриваем бассейн Аденского залива, простирающийся несколько дальше на восток, до восточной оконечности плато и острова Сокотра, являющихся естественным продолжением Африканского материка, и даже до трансформного разлома Оуэн. Аденский залив, несмотря на расположение между двумя континентальными блоками, является относительно глубоководным (для залива) бассейном: средняя глубина составляет 500 м, максимальная 4525 м. Большая часть его дна, за исключением узких шельфовых зон и континентальных склонов, характеризуется глубинами от 1 до 2 км в западной части, от 2 до 3 км в центральной и от 3 до 4 км в самой восточной части залива. Залив имеет все морфологические провинции, присущие океанам: континентальные окраины (пассивные), океанические котловины и срединный хребет с выраженной рифтовой долиной и поперечными смещениями трансформного типа. Все структуры четко отражаются в рельефе дна и аномальных геофизических полях (рис. 2, а-г).

Центральную зону бассейна Аденского залива занимает спрединговый хребет, протягивающийся на расстояние $\approx 1500$ км с генеральным северо-восточным простиранием $75^{\circ}$. Он характеризуется ультрамедленными значениями скоростей спрединга, которые увеличиваются с запада на восток от 1.3 до 1.8 см/год, достигая вблизи трансформного разлома Оуэн значений 2.4 см/год [Bosworth et al., 2005]. Рифт Аденского залива простирается под острым углом к направлению растяжения (в среднем $40-50^{\circ}$ ), то есть спрединг

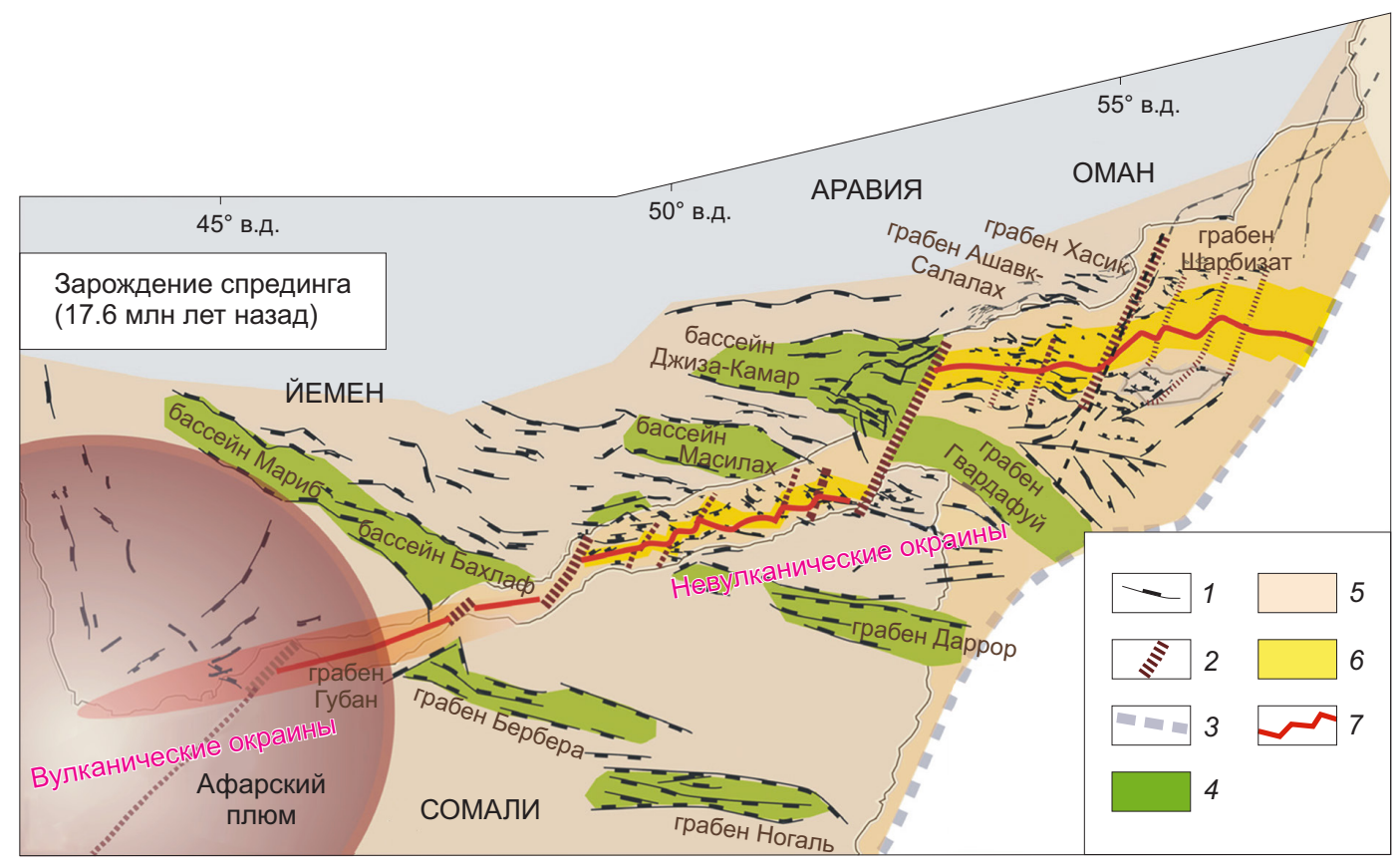

Рис. 1. Схема строения Аденского региона до начала спрединга (17.6 млн лет), показывающая расположение бассейнов, которые были реактивизированы в течение последнего эпизода рифтинга, приведшего к расколу континента и океаническому спредингу [Leroy et al., 2012; Korostelev et al., 2015a].

1 - сбросы; 2 - трансферные зоны (будущие трансформные разломы); 3 - граница Африкано-Аравийского шельфа; 4 - реактивизированные унаследованные грабены; 5 - область, подверженная олигоцен-миоценовому рифтингу; 6 - переходная зона от континента к океану; 7 - ось палеохребта на время 17.6 млн лет (хрона A5d).

Fig. 1. Schematic map showing the Gulf of Aden just before the onset of oceanic spreading (17.6 Ma) (after [Leroy et al., 2012; Korostelev et al., 2015a]). The map shows the locations of pre-existing basins that were reactivated during the last episode of rifting which led to continental breakup and oceanic spreading.

1 - normal faults; 2 - transfer zones, i.e. future transform faults; 3 - boundary of the Arabia/Africa shelf; 4 - reactivated inherited grabens; 5 - area affected by Oligo-Miocene rifting; 6 - ocean-continent transition zone; 7 - paleo-ridge axis at 17.6 Ma (chron A5d). 
в данном регионе косой. Благодаря этому рифтовая зона Аденского залива отличается высокой степенью сегментации и большим количеством трансформных смещений.

Спрединговый хребет возвышается на 2.4-2.5 км над дном прилегающих периферических котловин Аденского залива, подстилаемых океанской корой позднемиоценового и более молодого возраста. Он характеризуется сильно расчлененным рельефом. Центральная часть хребта осложнена рифтовой долиной глубиной в 1.5-2.0 км, заканчивающейся на западе в заливе Таджура, где она смыкается с континентальными рифтами треугольника Афар (см. рис. 1). На востоке рифтовая зона Аденского залива соединяется с рифтовой зоной спрединговых хребтов Индийского океана посредством спредингового хребта Шеба, ограниченного на востоке трансформным разломом Оуэн. Хребет Шеба рассечен трансформными разломами северо-восточного простирания со смещениями оси спрединга до 180 км. Часто следы трансформных разломов находят свое продолжение на обоих берегах Аденского залива и особенно отчетливо выражены на побережье Йемена.

В пределах глубоководной части акватории залива, ниже осадочных толщ, по сейсмическим данным выделяют слой мощностью 2-3 км со скоростью продольных волн около 3.95-4.30 км/с и слой со скоростью 6.45-6.90 км/с. Очевидно, они могут соответствовать второму и третьему слоям океанической коры. Ниже, на глубине около 10 км, местами обнаружен слой со скоростью 7.5-7.8 км/с [Leroy et al., 2010b].

В настоящее время рифтовая долина продвигается с востока на запад, в глубь Африканской плиты в сторону Афарской депрессии. Здесь происходит переход от континентального рифтинга к океаническому спредингу. Типично океаническая кора в Аденском заливе сменяется утоненной континентальной при движении с востока на запад в пределы материка.

Несмотря на то, что общая схема эволюции региона Аденского залива достаточно хорошо известна по линейным магнитным аномалиям и другим геолого-геофизическим данным (см. ниже), нельзя игнорировать дискуссионные проблемы, возникающие при детальном рассмотрении этого района. Среди них можно выделить следующие: 1. Каковы условия и механизмы соединения континентального рифта с океаническим рифтом спредингового хребта Шеба и хребта Карлсберг? 2. В каком направлении осуществлялось продвижение рифтов в восточной провинции: из океана в континент
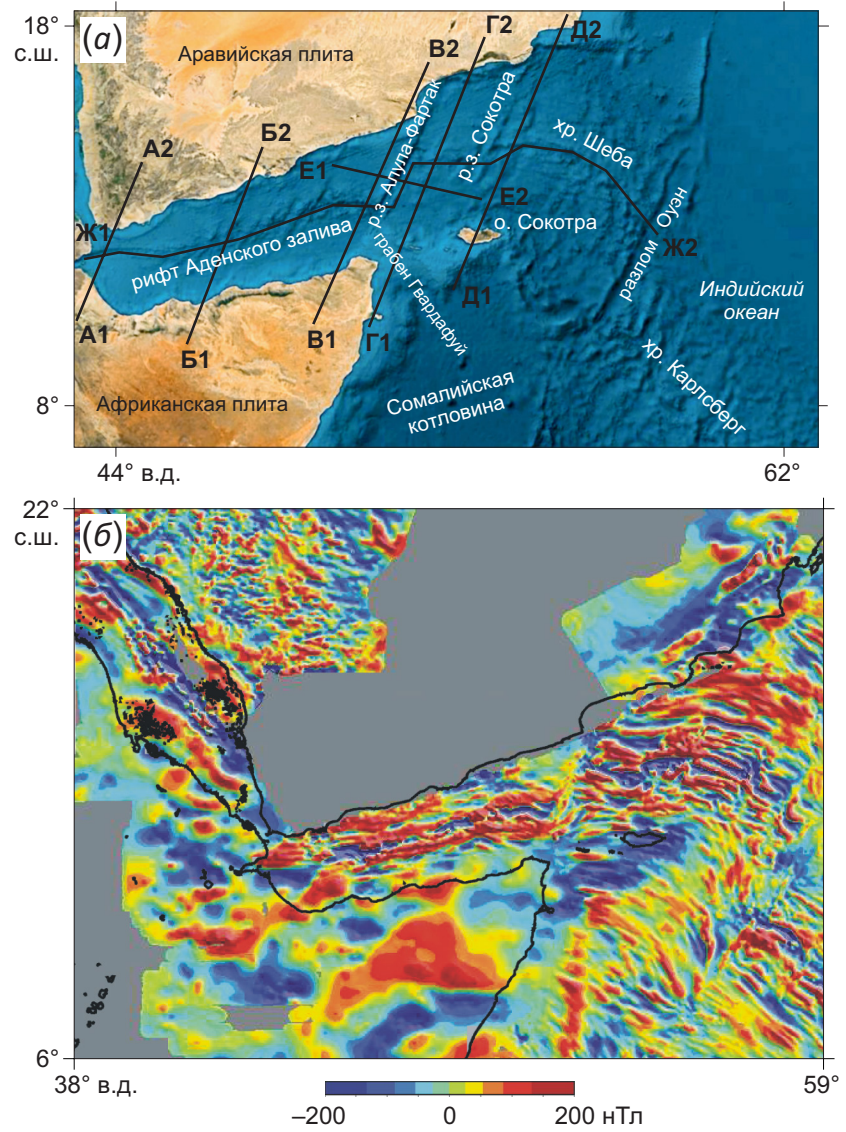
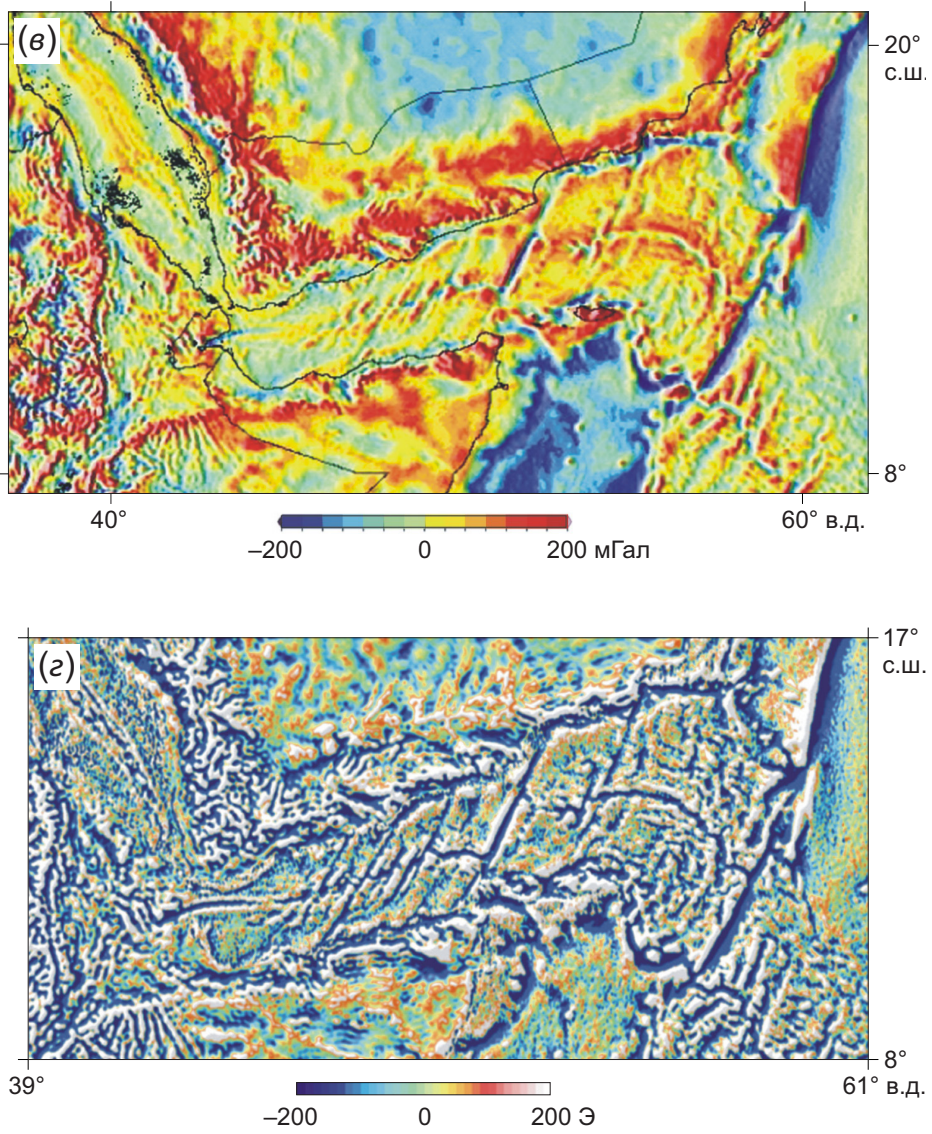

Рис. 2. Геофизическая характеристика Аденского залива: (a) - рельеф дна [Weatherall et al., 2015]; (б) - магнитное поле [Maus et al., 2009]; (в) - гравитационные аномалии в свободном воздухе [Smith, Sandwell, 1997]; (2) - вертикальный гравитационный градиент [Sandwell et al., 2014].

Fig. 2 Geophysical characteristics of the Gulf of Aden: (a) - bottom topography [Weatherall et al., 2015]; (6) - magnetic anomalies [Maus et al., 2009]; (8) - free-air gravity anomalies [Smith, Sandwell, 1997]; (2) - vertical gravity gradient [Sandwell et al., 2014]. 
или из континента в океан? 3. Каково влияние Афарского плюма на магмоснабжение (усиление активности 16-10 млн лет назад) и на развитие осевой сегментации спредингового хребта (условия формирования небольших трансформных разломов и нетрансформных смещений)? Возможна ли смена направления продвижения рифтов в результате увеличения интенсивности магмоснабжения? 4. Каково влияние унаследованных структур (мезозойских грабенов) на продвижение рифтов и на возможность формирования трансформных разломов? 5. Каковы условия образования континентального блока погруженного краевого плато и острова Сокотра? Частично пролить свет на эти проблемы и дать ответы на некоторые вопросы структурообразования можно с помощью физического моделирования.

Имеющаяся в настоящее время геолого-геофизическая информация свидетельствует о большом разнообразии морфотектонических структур, формирующихся в процессе континентального рифтогенеза и океанического спрединга. Это разнообразие обусловлено, прежде всего, геодинамической обстановкой и кинематикой плит, особенностями глубинного строения и гетерогенностью дораскольной коры, термическим состоянием литосферы, перескоками и изменениями геометрии осевой зоны спрединга.

Для понимания закономерностей и особенностей структурообразования в Аденском заливе мы использовали метод физического моделирования. Его эффективность была проиллюстрирована во многих публикациях, посвященных исследованию структурообразования в континентальных рифтах, в рифтовых зонах спрединговых хребтов и трансформных разломах. Теоретические и методологические аспекты метода были рассмотрены в работах [Belousov, Gzovsky, 1964; Gzovsky, 1975; Goncharov et al., 2005], а общие закономерности структурообразования при рифтогенезе исследовались в работах [Shemenda, 1984; Allemand, Brun, 1991; Malkin, Shemenda, 1991; Michon, Merle, 2003; Tirel et al., 2006; Konstantinovskaya et al., 2007; Nestola et al., 2013, 2015]. В работах Мак Клея с соавторами рассмотрено структурообразование в условиях многофазного растяжения [McClay, Ellis, 1987; Keep, McClay, 1997; McClay et al., 2002]. Немало работ посвящено продвижению рифтов в условиях косого растяжения [Withjack, Jamison, 1986; Bonini et al., 1997; Mart, Dauteuil, 2000; Agostini et al., 2009], в том числе в условиях разной прогретости мантии [Sokoutis et al., 2007; Autin et al., 2010; Bellahsen et al.; 2013a]. Наиболее изученными континентальными рифтами, на примере которых отрабатывались многие методические приемы физического моделирования, являются Байкальский рифт [Sherman et al., 1983, 1992; Logachev et al., 2000; Seminskii, Kogut, 2009; Corti et al., 2011; Seminsky, 2012; Bornyakov et al., 2014] и Восточно-Африканская рифтовая система, включающая Главный эфиопский рифт [Bonini et al., 1997; Agostini et al., 2011; Corti, Manetti, 2006; Corti, 2012; Corti et al., 2007, 2013; Brune et al., 2017; Zwaan et al., 2016], Красноморскую [Molnar et al., 2017] и Аденскую ветви [Dauteuil et al., 2001; Autin et al., 2010, 2013; Brune, Autin, 2013]. В пределах Восточно-Африканской рифтовой системы имеется большое разнообразие обстановок континентального рифтинга, переходящих в океанический спрединг. При этом в неотектоническом строении региона можно наглядно наблюдать структуры, находящиеся на разных стадиях развития рифтогенеза. Помимо континентального рифтогенеза с помощью физического моделирования широко исследовались осевые зоны спрединговых хребтов [Shemenda, Grokholsky, 1994; Dauteuil et al., 2001; Grokholskii, Dubinin, 2006; Kokhan et al., 2012; Grokholsky et al., 2014; Dubinin et al., 2011, 2017], а также сдвиговые деформации в приуроченных к ним трансформных и нетрансформных смещениях [Shemenda, Grokholsky, 1991; Dauteuil et al., 2002; Mauduit, Dauteuil, 1996; Dauteuil, Mart, 1998; Tentler, 2003, 2007; Tentler, Acocella, 2010; Grokholskii, Dubinin, 2006, 2010; Gerya, 2012; Dooley, Schreurs, 2012; Kokhan et al., 2012; Grokholsky et al., 2014; Dubinin et al., 2017].

В контексте наших исследований следует отметить работы [Autin et al., 2010, 2013; Brune, Autin, 2013; Bellahsen et al., 2013b], посвященные физическому моделированию структурообразования в рифтовой зоне Аденского залива в условиях косого растяжения и наличия структурных неоднородностей в дораскольной литосфере.

Таким образом, на примере Аденского залива представляется уникальная возможность изучать структуры, образующиеся при переходе от континентальной фазы растяжения литосферы к первым стадиям океанического спрединга. Целью настоящей работы является рассмотрение особенностей тектонического строения коры Аденского залива и проведение физического моделирования для выявления геодинамической природы особенностей структурообразования.

\section{2. СТРОЕНИЕ И СЕГМЕНТАЦИЯ РИФТОВОЙ ЗОНЫ}

Анализ рельефа дна и аномальных геофизических полей показывает, что в пределах Аденского залива выделяются три провинции (сегмента) - восточная, центральная и западная, которые имеют различное строение, эволюцию и морфоструктурную сегментацию рифтовой зоны (рис. 3). Эти провинции разделены крупными трансформными разломами Шукра-Аль-Шейх и Алула-Фартак [Bellahsen et al., 2013b; Brune, Autin, 2013; Leroy et al., 2010a, 2012]. На батиметрических профилях (рис. 4) отчетливо видны различия в рельефе дна этих провинций: он значительно более сглажен в западной провинции, отмечается общее понижение глубин дна с запада на восток. Продольный профиль отражает уменьшение глубин рифтовой долины с востока на запад, что, видимо, связано с продвижением оси спрединга в этом направлении, повышением прогретости мантии и уменьшением возраста коры.

Западная провинция Аденского залива протягивается на 250 км от мелководного залива Таджура (где Аденский рифт примыкает к области Афар) до зоны разлома Шукра-Аль-Шейх. Ширина бассейна достигает 260 км. 
Спрединг с ультрамедленной скоростью $\approx 1$ см/год начался здесь 3-2 млн лет назад. Рельеф дна в западной части Аденского залива представлен шельфовыми зонами (на северном побережье ширина в среднем 10 км, на южном - 5 км), материковым склоном, ложем океана с молодой океанической корой и формирующимся спрединговым хребтом. Спрединговый хребет западной провинции значительно моложе участка Аденского хребта, расположенного к востоку, в рельефе дна он выражен менее контрастно. Рифтовая долина достигает глубины 1500 м. В отличие от центральной и восточной провинции, осевой грабен здесь не обрамлен рифтовыми горами (рис. 4, пр. А1-А2). Трансформные разломы в этой провинции практически отсутствуют. В осевой зоне Аденского рифта в западной провинции распространены нетрансформные смещения. Отсутствие трансформной сегментации связывается с влиянием Афарской горячей точки и более пластичной литосферой.

Центральная провинция занимает большую часть Аденского залива (примерно 660 км). На западе она ограничена трансформным разломом Шукра-Аль-Шейх, на востоке - трансформным разломом Алула-Фартак. Океаническая кора в этой провинции начала образовываться около 10 млн лет назад. Рельеф сегмента в целом выровнен, бассейн имеет U-образное строение (рис. 4, пр. Б1-Б2 и пр. В1-В2). Ширина шельфа не превышает 5 км. Материковый склон более крутой, чем в западной провинции. Поперечный профиль становится более симметричным - ширина ложа и на севере, и на юге примерно одинакова и составляет около 50 км. Обрамленная хребтами рифтовая долина узкая и глубокая (до 3500 м ниже уровня моря). Рельеф гораздо контрастнее, чем в западной провинции, так как литосфера здесь более мощная, а спрединг начался на несколько миллионов лет раньше. В этой провинции становится заметным влияние косого спрединга - хорошо развита сегментация трансформными разломами, имеющими северо-восточное простирание: наблюдается один крупный трансформный разлом и несколько небольших трансформных разломов со смещениями оси до 30 км. Следы трансформных разломов четко отражаются в рельефе и в аномальных полях и часто находят свое продолжение на сопряженных окраинах Аденского залива. Наиболее крупный трансформный разлом Алула-Фартак смещает ось спрединга на 180 км. Морфологически он представляет собой V-образную трансформную долину с относительной глубиной до 3000 м и абсолютной - до 5000 м (рис. 4, пр. Е1-Е2). Видимо, важную роль в образовании трансформных разломов играли наследуемые грабены мезозойского возраста на дораскольной континентальной коре [Bellahsen et al., 2013a].

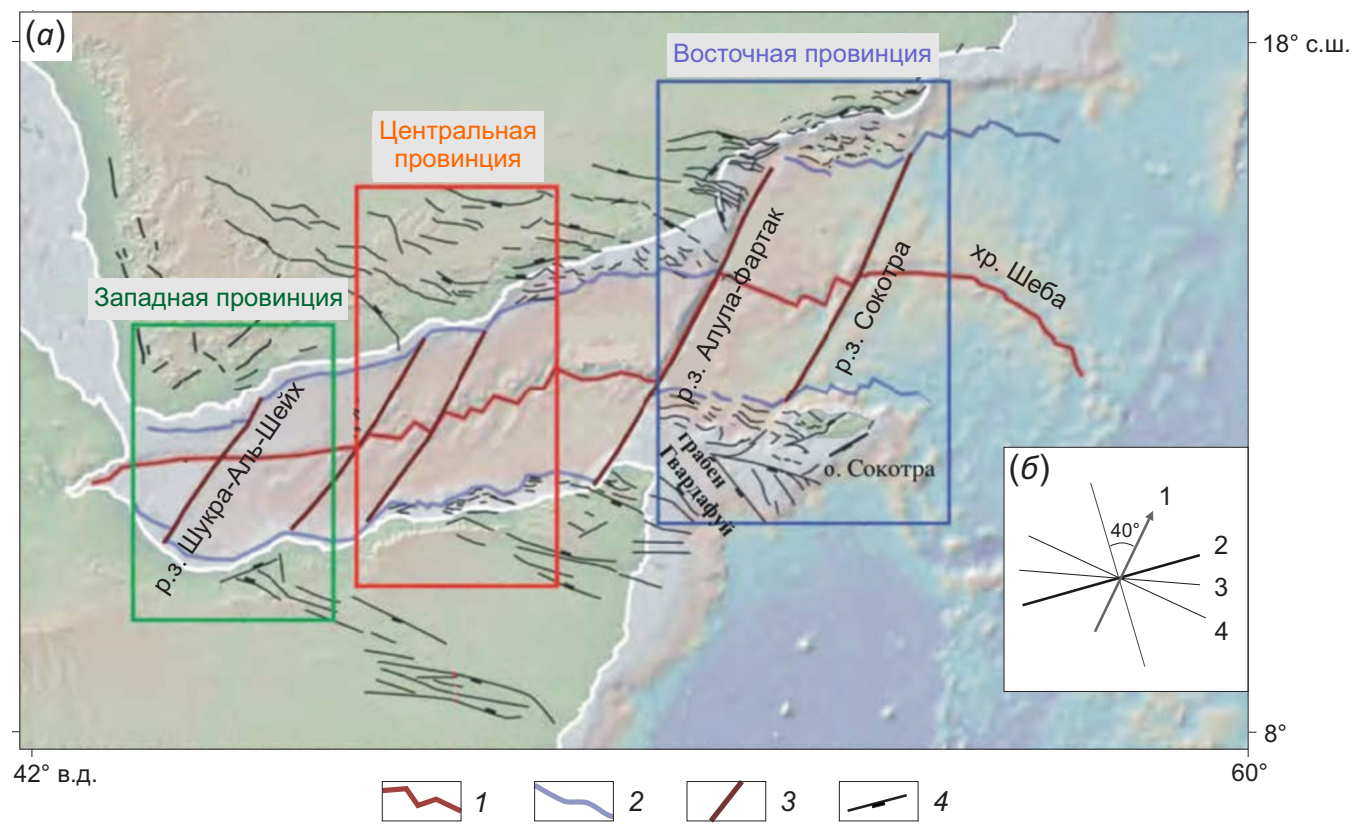

Рис. 3. Провинции Аденского залива с различной морфоструктурной сегментацией спредингового хребта и историей развития (по [Bellahsen et al., 2013b], с упрощениями).

(a): 1 - спрединговый хребет; 2 - граница «континент - океан»; 3 - трансформные разломы; 4 - сбросы. (б): 1 - направление раздвижения; 2 - разломы, параллельные простиранию Аденского залива и спредингового хребта (C75ㅅ); 3 -разломы с промежуточным простиранием $\left(\mathrm{C}^{\circ}{ }^{\circ} \mathrm{B}\right) ; 4$ - разломы с ортогональным смещением (C115응. Основные направления разломов (по [Brune, Autin, 2013], с небольшими изменениями).

Fig. 3. Provinces of the Gulf of Aden, which differ in morphostructural segmentation of the spreading ridge and their development history (simplified after [Bellahsen et al., 2013b]).

(a): 1 - spreading ridge; 2 - ocean-continent boundary; 3 - transform faults; 4 - normal faults. (б): 1 - divergence; 2 - faults parallel of general trend of the Gulf of Aden and the spreading ridge (N075 $\mathrm{E}) ; 3$ - faults with an intermediate strike (N095 ${ }^{\circ}$ ); $4-$ orthogonal $^{\circ}$ displacements $\left(\mathrm{N} 115^{\circ} \mathrm{E}\right)$. Fault trends after [Brune, Autin, 2013], with minor changes. 
A1

Западный сегмент

A2

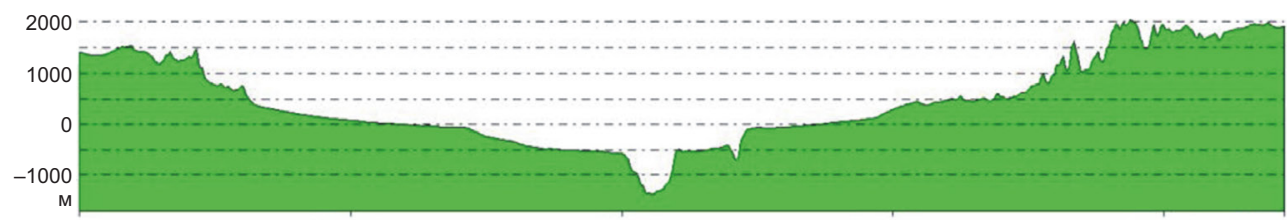

Б1

Бассейн Бербера Центральный сегмент

52

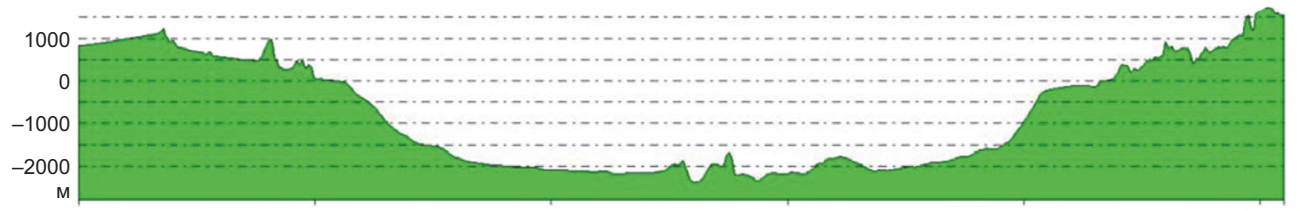

B1

Бассейн Даррор

Центральный сегмент

B2

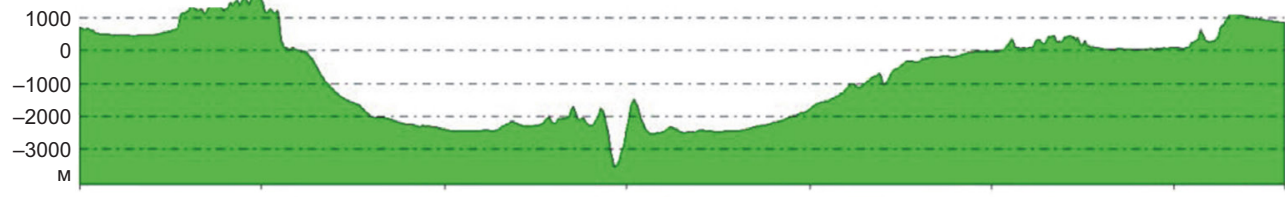

$\Gamma 1$

Восточный сегмент (зона подводных гор)

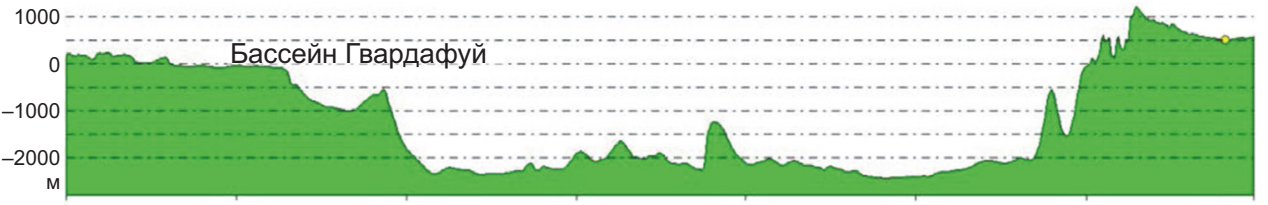

Д1

Восточный сегмент

Д2

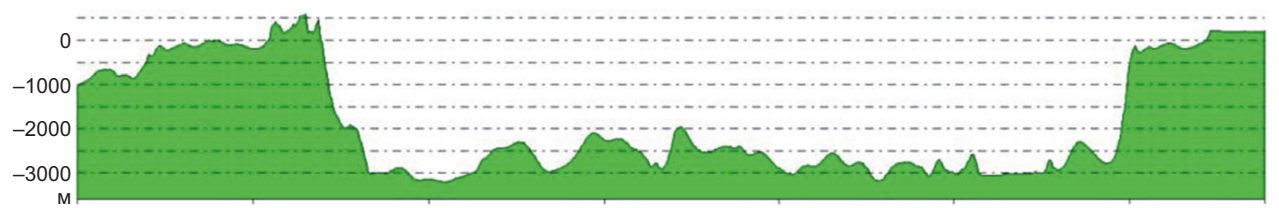

E1

р.з. Алула-Фартак

E2

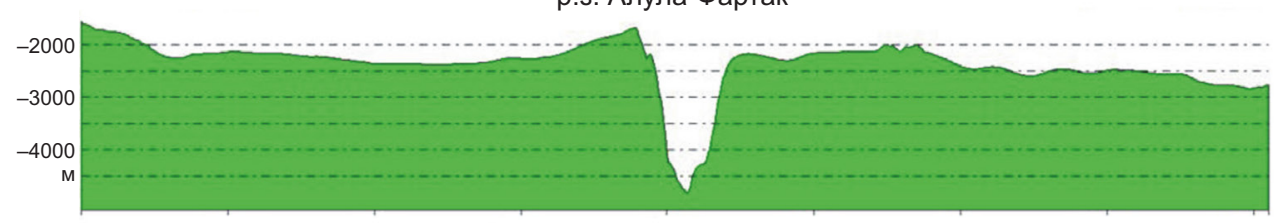

ж1

Центральный сегмент $\quad$ р.з. Алула-Фартак

Восточный сегмент

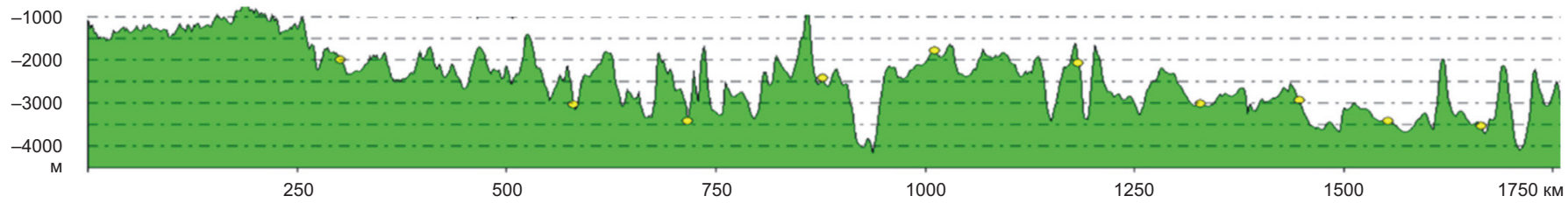

Рис. 4. Поперечные (А-Д) и продольный (Ж) профили через бассейн и осевую рифтовую зону Аденского залива [The GEBCO_08 Grid, 2009]. Положение профилей см. на рис. 2, а.

Fig. 4. Transverse (А-Д) and longitudinal (Ж) profiles across the basin and the axial rift zone of the Gulf of Aden [The GEBCO_08 Grid, 2009]. See Fig. 2, a for the positions of the profiles. 
Восточная провинция располагается между трансформным разломом Алула-Фартак и восточной оконечностью острова Сокотра. Поперечный профиль рельефа дна через эту провинцию симметричен и характеризуется очень крутым континентальным склоном (см. рис. 4, пр. Г1-Г2 и Д1-Д2). Рельеф рифтовой зоны спредингового хребта Шеба здесь весьма расчлененный с перепадом высот до 1000 м. Относительная высота хребта - 2.4-2.5 км [d'Acremont et al., 2005; Fournier et al., 2010]. Рифтовая долина глубиной 1.5-2.0 км не всегда четко выражена. Ширина долины по бровкам варьируется от 25 до 50 км, ширина днища до 5 км. К востоку уровень расчлененности снижается, это обусловлено тем, что восточная часть хребта формировалась на древней более однородной океанической коре. Следует подчеркнуть важную геодинамическую роль хребта Шеба в «соединении» рифтовой зоны Аденского залива с рифтовой зоной спредингового хребта Карлсберг в Индийском океане. Видимо, с этим связано постепенное изменение геометрии и простирания спредингового хребта на юго-восточное и асимметрия спрединга: полускорости выше к северу, чем к югу (1.3-1.4 см/год и 0.9-1.0 см/год, соответственно) [Fournier et al., 2010]. В восточной провинции наблюдается асимметрия и в строении океанической коры. К северу от хребта Шеба кора тоньше, чем к югу. Это также может быть следствием асимметричного спрединга, обусловленного небольшими перескоками оси. Возможно, имело место встречное продвижение рифтов в этом районе, приводящее к повышенному магмоснабжению в период от 9 до 16 млн лет назад. Это предположение подтверждается существованием подводных вулканических гор в пределах этого сегмента [d'Acremont et al., 2010].

Важным тектоническим элементом восточной провинции являются погруженное краевое плато и архипелаг Сокотра, которые отделяются от Сомалийской плиты грабеном Гвардафуй (см. рис. 2, а). Сокотра является самым большим из четырех островов (Сокотра, Дарса, Самха и Абд-эль-Кури), составляющих архипелаг Сокотра. Он расположен примерно в 380 км к югу от мыса Рас Фартук (Йемен) и примерно в 250 км к востоку от Рога Африки. Наибольшая глубина дна в области островов достигает около 2500 м на севере архипелага. Платформа Сокотры (шириной около 70 км) к югу от островов имеет глубины менее 250 м. К югу от платформы Сокотры дно океана погружается до $\approx 5000$ м в Северо-Сомалийской котловине [Birse et al., 1997].

С началом рифтинга были реактивированы образованные ранее мезозойские структуры. Наиболее ярко это проявилось в грабене Гвардафуй, который отсекает цоколь самого западного в архипелаге о-ва Абд-эльКури от шельфа современной восточной оконечности Африканского Рога (м. Гвардафуй, Сомали) [Lukashov, 2013]. Ширина грабена составляет около 50 км по днищу и около 80 км по бровкам. Углубление данного щелевидного асимметричного грабена, дно которого наклонено на ССВ, а глубина относительно бровок бортов превышает 1500 м, способствовало окончательной изоляции архипелага Сокотра от Африканского материка [Bellahsen et al., 2013b]. При растяжении также имели место значительные деформации всего плато: Сокотрийский блок испытал вращение.

\section{3. ЭВОЛЮЦИЯ БАССЕЙНА АДЕНСКОГО ЗАЛИВА} 3.1. Основные этапы развития

Дорифтовая структура литосферы Красного моря, Афара и Аденского залива была сформирована во время неопротерозойского панафриканского орогенеза [Bosworth et al., 2005]. Информация, по которой можно расшифровать эволюцию бассейна Аденского залива, в основном представлена линейными магнитными аномалиями, а также породами, формировавшимися в пределах дораскольной континентальной коры. В истории развития бассейна современного Аденского залива можно выделить пять этапов: 1) дорифтинговое развитие, 2) мезозойский континентальный рифтинг, 3) континентальный рифтинг в олигоцен-миоцене, 4) начало океанического спрединга в миоцене, 5) продвижение рифта в западном направлении в залив Таджура к тройному соединению Афар. Как было отмечено выше, континентальная кора в данном регионе сформировалась в докембрийское время, а в течение всего палеозоя была подвержена выветриванию и эрозии. Первая фаза рифтинга засвидетельствована в мезозое. Сформировались грабены, имеющие в среднем северо-западное простирание. Синрифтовые отложения в этих грабенах имеют возраст от поздней юры до раннего мела. Наиболее полно представлены отложения в бассейне Бербера, который был сопряжен с бассейном Балхаф в доолигоценовой конфигурации плит [Bosworth et al., 2012]. Вторая фаза рифтинга состоялась в олигоцене миоцене. Кайнозойские дорифтовые отложения представлены в основном эвапоритами. Синрифтовые отложения располагаются вдоль континентальных окраин, в бассейнах Балхаф, Камар и других. Точное время начала континентального рифтинга в Аденском заливе неизвестно. Рифтовые отложения, найденные в Йемене, имеют возраст 35.0-28.4 млн лет [Bosworth et al., 2005; d'Acremont et al., 2005, 2006, 2010; Leroy et al., 2010b, 2012]. В западной провинции Аденского региона не обнаружено отложений, которые свидетельствовали бы о растяжении до 31 млн лет, то есть до начала плюмового вулканизма в Афаре. На начальное место формирования континентального рифта могло оказать влияние положение хребта Карлсберг в Индийском океане.

Граница между синрифтовыми и пострифтовыми отложениями попадает в интервал времени 21.1-17.4 млн лет назад. Это время может считаться переходом от континентального рифтинга к спредингу [Bellahsen et al., 2013b], когда центр спрединга Аденского залива через хребет Шеба соединился с мировой системой СОХ в Индийском океане. Рифтинг в районе Аденского залива реактивировал многие мезозойские рифтовые грабены, которые могли контролировать геометрию рифтовой зоны и последующих трансформных разломов [Bosworth et al., 2012]. 
Расшифровка линейных магнитных аномалий позволила построить довольно точную карту возраста коры Аденского залива и на ее основе модель эволюции океанического бассейна. Так, в Аденском заливе выделяется три основных стадии продвижения спредингового хребта [Huchon, Khanbari, 2003; Fournier et al., 2010] (рис. 5).

Первая стадия, около 20 млн лет назад (незадолго до хрона 6, который относится к возрасту 19.7 млн лет), выражается в формировании участка хребта длиной 200 км (рис. 5, а, б). Этот самый восточный сегмент заложился на древней океанической коре позднеюрского - раннемелового возраста. Спрединговый сегмент имеет простирание $130^{\circ} \mathrm{B}$, располагается юго-восточнее острова Сокотра и ограничивается разломом Оуэн с востока, а с запада - восточной африканской границей континент - океан. Вслед за ним, перед аномалией 5D (17.5 млн лет), развился спрединговый сегмент центральной провинции длиной 500 км (рис. 5, б). Он протянулся далее на запад вплоть до трансформного разлома Алула-Фартак и состоял из шести сегментов, разделенных пятью трансформными разломами со смещением около 50 км. В восточной части этой области окраина о. Сокотра и окраина Аравийского полуострова при совмещении по изобате 500 м не совпадают. Образуется пробел, который не фиксируется в линейных аномалиях, тогда как в более западных частях залива контуры этой изобаты совмещаются очень хорошо. Согласно [d'Acremont et al., 2005], кора этого участка является сильно растянутой континентальной. К востоку от разлома Сокотра спрединговый центр был смещен к югу и располагался вблизи о. Сокотра. Здесь он разделяет две сопряженные асимметричные в плане континентальные окраины. Ширина северной окраины составляла $\approx 100$ км, а южной $\approx 30$ км [Fournier et al., 2007, 2010]. На северной окраине преобладали горсты и грабены, а крутая и узкая южная окраина маркировалась одним главным, падающим к северу сбросом-детачментом. Такой же характер асимметрии наблюдался вдоль сегмента, расположенного непосредственно к западу от разлома Сокотра [d'Acremont et al., 2005]. Продвижение рифта к западу прекратилось приблизительно на 1 млн лет. Оно возобновилось незадолго до аномалии 5С (16 млн лет назад) (рис. 5, в) и привело к формированию третьего сегмента хребта в западной части Аденского залива от трансформного разлома (ТР) Алула-Фартак до $45^{\circ}$ в.д. Участок длиной 700 км был сегментирован серией, по меньшей мере, из восьми левосторонних трансформных разломов (рис. 5, г). На этом участке рифтовая трещина продвигалась очень быстро (>45см/год), пересекая существующие в дораскольной афро-аравийской литосфере мезозойские горсты и грабены, имеющие ЗСЗ - ВЮВ простирание [Fournier et al., 2010]. Приблизительно 16 млн лет назад произошло изменение направлений движения между Аравийской и Индийской плитами. Видимо, это обстоятельство привело к реорганизации структурной сегментации рифтовой оси в центральной провинции [Huchon, Khanbari, (a)

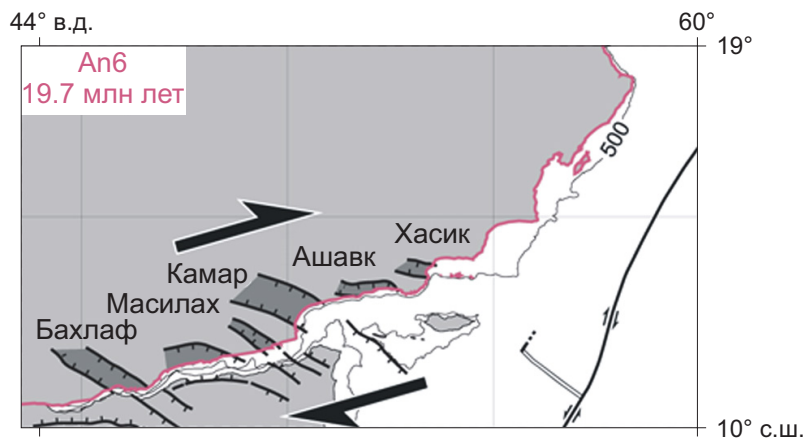

(б)

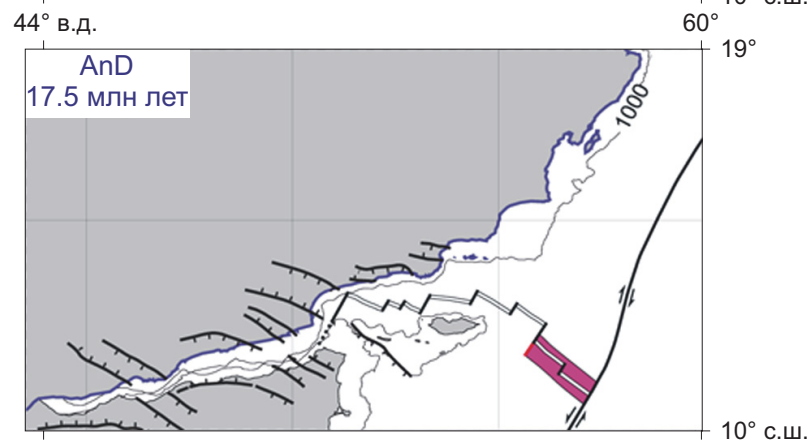

(8)

$$
44^{\circ} \text { в.д. }
$$

$60^{\circ}$
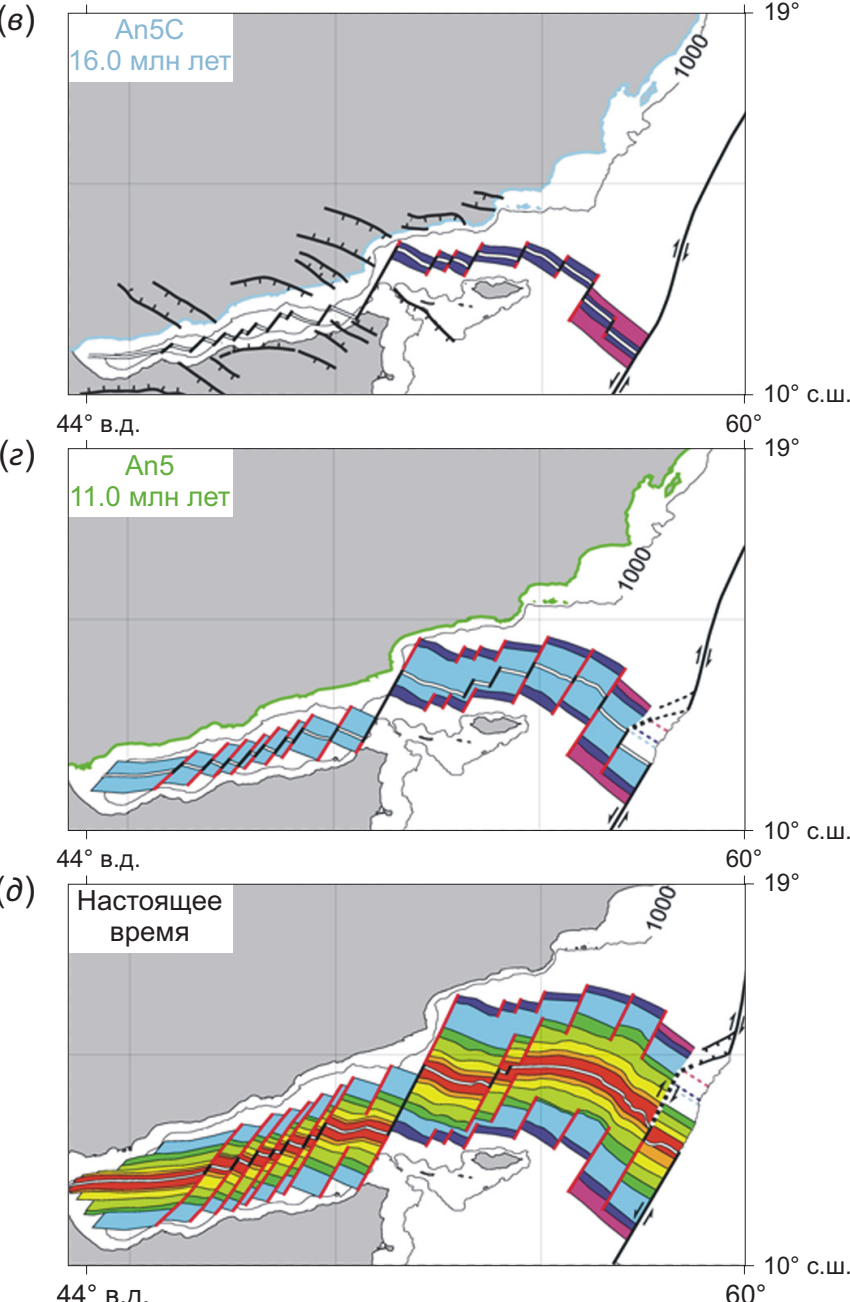

Рис. 5. Реконструкция раскрытия Аденского залива, иллюстрирующая разные стадии эволюции и продвижения рифтовой трещины хребта Шеба к западу в сторону Афарского плюма и эволюция осевой сегментации (по [Fournier et al., 2010], с упрощениями). 
(a) - спрединг между Аравией и Сомали начался $\approx 20$ млн лет назад непосредственно перед аномалией 6 (19.7 млн лет), самой древней в Аденском заливе; (б-2) - быстрое продвижение (со средней скоростью 350 км/млн лет) рифтовой трещины к западу и формирование океанической коры на всем протяжении Аденского залива. Продвижение хребта по всей длине Аденского залива завершилось на хроне 5С (16.0 млн лет); ( $\partial$ ) - современное положение спредингового хребта.

Fig. 5. Reconstructed opening of the Gulf of Aden. Westward propagation of the rift fault (Sheba ridge) toward the Afar mantle plume and the evolution of axial segmentation are shown simplified after [Fournier et al., 2010].

(a) - seafloor spreading between the Arabia and Somalia plates started $\approx 20 \mathrm{Ma}$ ago, shortly before anomaly 6 (19.7 Ma), the oldest magnetic anomaly recognized in the Gulf of Aden; $(6-2)$ - fast propagation ( $350 \mathrm{~km} / \mathrm{Ma}$ on average) of the rift fault to the west and the formation of the oceanic crust all along the Gulf of Aden. The Sheba ridge propagation in most of the Gulf of Aden was completed at chron $5 \mathrm{C}(16.0 \mathrm{Ma}) ;(\partial)$ - current position of the spreading ridge.

2003; Fournier et al., 2010]. Таким образом, продвижение спредингового хребта на расстояние более 1400 км случилось за крайне короткий срок, не превышающий 4 млн лет, со средней скоростью 35 см/год. Дальнейшее продвижение западной части хребта в сторону депрессии Афар происходило еще быстрее - около 45 см/год [Fournier et al., 2010]. В рассмотренной эволюционной картине следует отметить некоторые особенности и дискуссионные моменты, позволяющие по-разному трактовать историю бассейна.

\section{2. Влияние Афарского плюма}

Афарский плюм, безусловно, оказывал и оказывает влияние на геодинамику и эволюцию района Аденского залива (см. рис. 1). Однако нельзя точно сказать, до какой степени оно распространяется. Предполагают, что именно влияние Афарского плюма предопределило значительный наклон рифта относительно направления растяжения. Считалось, что его активность была настолько сильной, что хребет Карлсберг, приближаясь к Африкано-Аравийскому шельфу, «почувствовал» влияние Афара и устремился к нему по наиболее короткому пути, особо не реагируя на мезозойские рифтогенные структуры [Dauteuil et al., 2001]. В дальнейшем обнаружились детали, заставляющие пересмотреть столь упрощенную точку зрения. Тщательному изучению подвергалась область, расположенная восточнее трансформного разлома Алула-Фартак, где была обнаружена серия подводных вулканических гор, а также установлены структурные линеаменты (псевдоразломы), свидетельствующие о продвижении оси спрединга с запада на восток (то есть противоположно общему тренду продвижения хребта), в период между аномалиями 5d и 5, около 17.5 и 11 млн лет [d'Acremont et al., 2005, 2006]. Подобные структуры нередко формируются при продвижении оси спредингового хребта в океанической коре [Dubinin, Ushakov, 2001]. В пользу этого говорит также асимметрия объемов наращенной океанической коры к северу и югу от оси спрединга.
Предполагается, что одной из возможных причин формирования таких структур стало локальное увеличение магмоснабжения, обусловленное деятельностью Афарского плюма. Но возможна и другая причина, связанная с тем, что рифт, продвигающийся с востока на запад, не смог сразу преодолеть структурный барьер с более прочной литосферой бассейна Джиза-Камар и проторазлома Алула-Фартак. Это могло привести к остановке миграции подосевого астеносферного потока и формированию в этой области локальных очагов плавления по механизму «дамбового» эффекта. После детального изучения аномального гравитационного поля была выявлена отрицательная остаточная аномалия Буге восточнее трансформного разлома АлулаФартак и южнее оси хребта. Эта аномалия интерпретируется как индикатор зоны частичного плавления, которая рассматривается как источник дополнительной магмогенерации для региона вследствие усиления активности Афарского плюма [Leroy et al., 2010a]. Кроме того, данные сейсмической томографии позволили установить область пониженных скоростей сейсмических волн под бассейнами Джиза-Камар (Йемен) и Ашафк-Салалах (Оман) вблизи аравийской окраины в окрестности разломной зоны Алула-Фартак, свидетельствующую о том, что магматизм здесь мог быть вызван мелкомасштабной конвекцией на контакте блоков литосферы с разной мощностью [Korostelev et al., 2015a, 2015b].

\section{3. Влияние гетерогенности литосферы}

Кроме Афарской горячей точки, на развитие Аденского залива, особенно на формирование структур в центральной и восточной провинциях, оказывало влияние гетерогенное строение континентальной литосферы и, прежде всего, наличие мезозойских грабенов.

Континентальная кора более гетерогенна и анизотропна, чем океаническая, а это значит, что особенности продвижения рифта зависят от ее взаимодействия с различными структурно-вещественными неоднородностями, встречающимися на его пути. В этом случае возможно несколько вариантов развития рифта. Если неоднородность менее прочная, чем окружающая кора, то рифтовая трещина, приближающаяся к ней, пройдет ее беспрепятственно с небольшими смещениями. Если же неоднородность более прочная, у рифта есть два пути: обогнуть ее или пытаться разрушить. В результате может происходить смещение рифтовой зоны по сдвиговым разломам трансформного типа или перескок рифтовой оси с образованием микроконтинентальных блоков. Однако литосфера структурной неоднородности может оказаться настолько прочной, что продвижение рифта будет значительно замедлено или даже остановлено, как, например, хребет Гаккеля в Северном Ледовитом океане, упирающийся в шельф моря Лаптевых, или Западный хребет Скоша, прекративший свою активную деятельность после «столкновения» с континентальным блоком Фолклендского плато [Dubinin et al., 2016]. 
В восточной провинции, по мнению многих исследователей [d'Acremont et al., 2006; Bellahsen et al., 2013a], благодаря гетерогенности литосферы и, прежде всего, наличию мезозойских грабенов с более прочной литосферой, сформировались крупные трансформные разломы (например, Алула-Фартак) и континентальный блок острова Сокотра с погруженным одноименным краевым плато. Первоначальная асимметрия северной и южной континентальных окраин и, возможно, асимметричный рифтинг привели к сильному утонению континентальной литосферы и деформации этого блока.

Теоретически самой труднопреодолимой структурно-вещественной границей для продвигающейся рифтовой трещины должна стать граница океан - континент. Особенности ее преодоления рифтовой трещиной будут определяться соотношением эффективной прочности океанической и континентальной литосферы, а также литосферы переходной зоны. Существенное влияние на эффективную прочность литосферы континентальных окраин будут оказывать геодинамические условия, в которых происходит переход от континентального рифтинга к океаническому спредингу (вулканические или невулканические условия, влияние горячей точки или гиперрастяжение континентальной коры, сопровождаемое подъемом серпентинизированной мантии). Если континентальная литосфера очень прочная за счет мощности подлитосферной мантии, то расколоть ее будет трудно. Для района Аденского залива такими структурными барьерами могли быть переходная зона от континента к Индийскому океану, мезозойские рифты и крупные трансформные разломы, такие как Алула-Фартак. Мезозойский грабен ДжизаКамар-Гвардафуй, который и стал структурным препятствием на пути продвигающегося рифта, скорее всего, имеет прочность выше, чем окружающая литосфера, из-за более тонкой рифтогенной континентальной коры. Ряд исследователей [d'Acremont et al., 2006] считают, что трансформный разлом Алула-Фартак образовался в результате обособленного развития двух рифтов, расположенных западнее и восточнее будущего трансформного разлома. Наличие встречного рифта западнее грабена может упростить ситуацию и позволить расколоть прочный блок и сформировать сдвиговую структуру. Более того, континентальный блок плато и острова Сокотра, возможно, мог сформироваться как результат перекрытия встречных рифтов. Северная ветвь в итоге стала приоритетной и дала начало развитию спредингового хребта Шеба, а в южной не произошло перехода от рифтинга к спредингу, и она перешла в пассивную стадию своего развития, сохранившись в виде авлакогена. В процессе последующего остывания значительная часть этого региона опустилась ниже уровня моря, сформировав краевое плато и о. Сокотра, которые оказались отделенными от континента грабеном Гвардафуй.

Таким образом, структурно-реологическая стратификация и гетерогенное строение дораскольной литосферы, а также степень прогретости мантии, вызванная влиянием афарского плюма, являются основными факторами, определяющими характер раскола континентальной литосферы, особенности строения переходной зоны (наличие погруженных континентальных плато или крупных магматических провинций) и, в конечном итоге, особенности этапа первоначального ультрамедленного спрединга и тектоническое строение молодого спредингового хребта.

\section{4. МЕТОДИКА ЭКСПЕРИМЕНТАЛЬНОГО МОДЕЛИРОВАНИЯ}

Методические принципы, используемые при физическом моделировании в данной работе, были разработаны ранее и рассмотрены в работах [Shemenda, Grokholsky, 1991; Grokholskii, Dubinin, 2006, 2010]. В них исследовались процессы деформации и разрушения коры в центральной зоне рифта, приводящие к образованию нетрансформных смещений и различных типов перекрытий локальных центров спрединга. Эти процессы изучались при различной толщине модельной литосферы и разных скоростях и направлениях растяжения. Эксперименты показали, что общей чертой процесса продвижения рифта при ортогональном и косом спрединге является формирование нетрансформных смещений разного типа.

В работах [Malkin, Shemenda, 1991; Shemenda, Grokholsky, 1994] на основе экспериментов по растяжению двухслойной модели литосферы рассматривались модели рифтинга и аккреции коры при медленном спрединге. В этих экспериментах верхний хрупкий слой разрушался с образованием многочисленных крутопадающих трещин. В пределах нижнего более пластичного слоя происходит утонение и формирование двух внутренних разломных зон, секущих плиту до основания. Клин, разделенный этими зонами, поднимается симметрично вверх. Затем движение клина прекращается вдоль одной из зон и продолжается вдоль другой. С этого момента деформации становятся асимметричными. Формирование разломов различного падения происходит с равной вероятностью, поэтому асимметрия спрединга меняет свое направление от сегмента к сегменту. Этот процесс сопровождается образованием нетрансформных смещений и трансформных разломов.

Согласно этой модели, деформации литосферного клина, особенно на стадии асимметричного вытягивания то в одну, то в другую сторону от оси спрединга, приводят к постепенному движению блоков (верхнего хрупкого слоя коры, разделенных сбросами) от внутреннего дна рифтовой долины на ее стенки, к рифтовым горам и далее на фланги срединного хребта.

Экспериментальная установка и модельное вещество подробно описаны в статьях [Shemenda, Grocholsky, 1991, 1994]. В наших исследованиях аналоговое моделирование тектонических процессов осуществлялось на той же самой экспериментальной установке, представляющей собой текстолитовую ванну с поршнем, приводимым в движение электромеханическим 
приводом (рис. 6). Последний позволял изменять скорости деформации модельной плиты и имитировать ортогональный или косой спрединг с переменными скоростями.

Текстолитовая ванна заполнена модельным веществом, которое представляет собой сплав жидких и твердых углеводородов. Свойства вещества зависят от состава, температуры и технологии его приготовления. При комнатной температуре вещество находится в твердом состоянии. На дне и боковых стенках ванны располагаются нагреватели. С их помощью модельное вещество плавится и доводится до определенной температуры, имитируя астеносферу (рис. 6, а). Затем вещество охлаждается сверху вентилятором при постоянной температуре в интервале от 22.5 до $25.5^{\circ} \mathrm{C}$ и кристаллизуется, образуя модельную литосферу (рис. 6, б). Изменение длительности охлаждения обеспечивало разную толщину модельной литосферы при разных соотношениях ее хрупкой и пластичных частей, которая подвергается впоследствии горизонтальному растяжению при движении поршня (рис. 6, в). Контроль за температурой осуществляется постоянно в процессе подготовки и проведения экспериментов. Деформация упругопластичной модельной литосферы, формирующая трещины и структуры различного ранга, осуществляется при постоянной комнатной температуре на поверхности слоя.

Согласно [Shemenda, 1983], подобие модели и природного оригинала в проведенных экспериментах определялось критерием

$$
\text { ' } \Omega=\tau_{\mathrm{s}} / \rho \mathrm{\rho H}=\text { const, }
$$

где $\tau_{s}$ - предел текучести на сдвиг, $\rho$ - плотность слоя, $\mathrm{H}-$ толщина слоя, g - ускорение свободного падения. Coблюдение этого условия требует использования крайне малопрочных материалов при моделировании литосферы, так как уменьшение масштаба процесса, как это должно быть в модели, требует уменьшения прочности используемых материалов. Если для природного оригинала литосферы принимаются значения параметров $\tau_{\mathrm{s}}{ }^{\circ}=(5.0-5.6) \cdot 10^{7}$ Па; $\rho^{\circ}=(2.8-3.0) \cdot 10^{3} \kappa г / \mathrm{m}^{3}$; $\mathrm{H}^{\circ}=(0.5-1.0) \cdot 10^{4} \mathrm{M}$, то в согласии с (1) для модельных параметров получаем оценки: $\tau_{\mathrm{s}}{ }^{\mathrm{M}}=20-30$ Па; $\rho^{\mathrm{M}}=$ $0.86 \cdot 10^{3}$ кг $/ \mathrm{m}^{3} ; \mathrm{H}^{\mathrm{M}}=(1-7) \cdot 10^{-3} \mathrm{м}$. Использование материалов с такими параметрами в экспериментах позволяет нам говорить о подобии процессов формирования осей спрединга в природе и модели, когда определяющим параметром процесса является эффективная прочность литосферы, поэтому модель воспроизводит в общих чертах реологическое поведение литосферы в осевой зоне рифта и картину разломов и трещин в ней. При однородном составе модельного вещества литосферы процесс его остывания создает, по сути, реологически двухслойную литосферу, верхняя часть которой деформируется как упругое тело, а нижняя - как пластичная среда, т.е имеет место поведение модельной литосферы, близкое к наблюдаемому в природе. Меняя температуру на поверхности и в основании модели, а также время остывания вещества, мы можем имитировать разломообразование в утоненной или утолщенной литосфере. При этом в модели не выполняются температурные условия подобия [Shemenda, 1983; Shemenda, Grocholsky, 1991, 1994], и, следовательно, модель не претендует на описание генерального рельефа COX, имеющего в основном термическое происхождение. Она описывает, как отмечалось выше, поведение литосферы в осевой зоне рифта шириной 10-20 км. В процессе растяжения литосферы расплавленное вещество поднимается в рифтовую трещину, кристаллизуется, формируя модельную океаническую литосферу и дальнейшее ее наращивание. Такой подход позволяет моделировать квазистационарный процесс спрединга и аккреции океанической коры [Shemenda, Grocholsky, 1994].

Эти эксперименты воспроизводят процессы кристаллизации и наращивание толщины модельной литосферы только снизу. Амплитуда рельефа, формируемого в модели, зависит от скорости растяжения и толщины модельной литосферы. Модель деформации литосферного клина воспроизводит перескоки спрединговой оси и в целом эволюцию внеосевого рельефа. В то же время, несмотря на соблюдение некоторых количественных критериев подобия [Shemenda, Grokholsky,

(a)

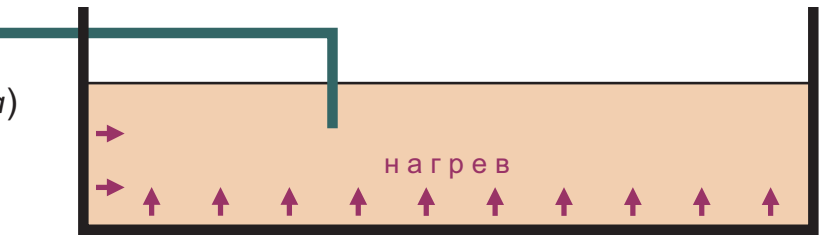

(б)

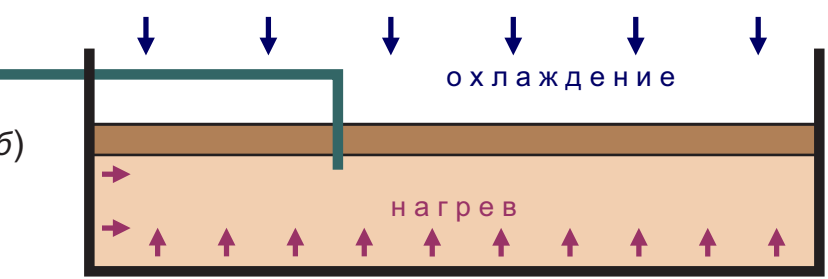

(B)

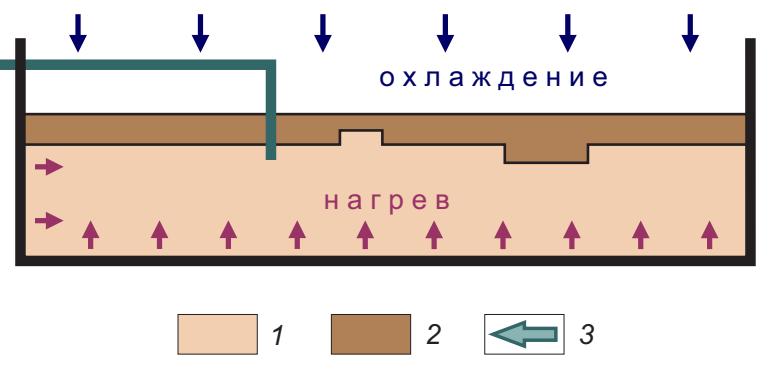

Рис. 6. Схема подготовки экспериментов с утоненной или утолщенной модельной плитой в разрезе. 1 - расплав; 2 модельная плита; 3 - направление движения поршня.

Fig. 6. Cross section showing preparation of experiments with a thinned or thickened model plate. 1 - melt; 2 - model plate; 3 direction of movement of the piston. 
1991, 1994], представленное моделирование не позволяет делать количественные оценки амплитуд формирующегося рельефа, ограничиваясь лишь качественной оценкой процессов формирования зон спрединга.

Таким образом, применяемая нами методика моделирования дает возможность исследовать структурообразование при рифтогенезе на региональном уровне. Однако у этой методики, как и у любой другой, есть свои недостатки. В отличие от численного моделирования, здесь невозможно абсолютно точно задавать и поддерживать одни и те же условия из эксперимента в эксперимент. Модель представляет собой открытую систему и подвержена влиянию колебаний комнатной температуры, а также чутко реагирует на неточности в подготовке эксперимента и внутренние неоднородности плиты, поэтому каждое усложнение модели, дабы максимально приблизить условия к природным, может пагубно сказаться на эксперименте. Это создает необходимость проведения большого количества схожих экспериментов, чтобы нивелировать отклонения при подготовке эксперимента. Также свойства модельного вещества не позволяют исследовать модель в разрезе, как это возможно при моделировании, например, на влажном песке. Кроме того, невозможно провести лазерное сканирование модельного рельефа в связи с поглощающими свойствами вещества.

\section{5. ОПИСАНИЕ ЭКСПЕРИМЕНТОВ И РЕЗУЛЬТАТЫ МОДЕЛИРОВАНИЯ}

В рамках настоящей работы экспериментальные исследования были проведены по двум направлениям:

1) изучение особенностей структурообразования и различий сегментации рифтовой зоны при разных кинематических режимах спрединга в восточной, центральной и западной провинциях;

2) исследование условий соединения континентального рифта Аденского залива с рифтовой зоной спредингового хребта Карлсберг.

В рамках нашей методики индикатором степени прогретости является толщина слоя модельной литосферы $\mathrm{H}_{1}$ и толщина литосферы в зоне рифтогенеза $\mathrm{H}_{2}$. Вариации толщины литосферы $\mathrm{H}_{2}$ в разных провинциях Аденского залива имели большое значение. В экспериментах это достигалось разным временем охлаждения литосферы рифтовой зоны.

Рифтовая зона задавалась в пределах модельной литосферы либо в виде вертикального разреза, либо в виде полосы утоненной модельной литосферы шириной w. Моделирование косого спрединга, характерного для Аденского залива, производилось следующим образом. В модели вырезался верхний слой $\mathrm{H}_{1}$ (до расплава) в полосе, ориентированной под углом $\alpha$ к направлению растяжения, соответствующим кинематической картине конкретной провинции (табл. 1). Далее этот участок подвергался дальнейшему охлаждению и наращиванию литосферы до толщины $\mathrm{H}_{2}$, меньшей, чем окружающая модельная литосфера. В экспериментах, здесь и далее, зона утонения модельного рифта (зона прогрева) формировалась с помощью создания ветровой тени соответствующей конфигурации или за счет подплавления снизу локальным, независимым источником нагрева.

Помимо толщины литосферы в экспериментах, описанных ниже, могли меняться ширина ослабленной утоненной зоны w (в среднем 3-5 см - десятки - первые сотни километров в природе) и скорость растяжения (в выбранном диапазоне скоростей $\mathrm{V}=(2-3) \cdot 10^{-5} \mathrm{M} / \mathrm{c}^{-1}$ ), соответствующая в природе миллиметрам - первым сантиметрам в год.

Были проведены серии экспериментов, реконструирующих характерные геотектонические процессы в изучаемом районе.

\section{1. Экспериментальная серия 1. Сегментация рифтовой трещины в восточной, центральной и западной провинциях}

Первое направление экспериментального моделирования (рис. 7) основано на предположении о том, что морфоструктурная сегментация оси спрединга в регионе Аденского залива зависит, в первую очередь, от степени прогретости и толщины литосферы, от косости спрединга и существования структурных неоднородностей с повышенной прочностью литосферы, связанных в данном случае с наличием серии мезозойских грабенов на дораскольном фундаменте. Возможно, важную роль играет также время существования спредингового хребта.

Восточный сегмент Аденского хребта (Шеба) в среднем ориентирован под углом около $70^{\circ}$ к направлению растяжения. В эксперименте литосфера сегмента в ослабленной зоне была выбрана достаточно толстой из-за удаленности района от Афарского плюма и расположения части сегмента на древней океанической литосфере. Соответствующий эксперимент (1447) представлен на рис. 8. На первом этапе растяжение привело к формированию в центральной части ослабленной зоны эшелона из четырех сегментов (рис. 8, а, б). Вдоль этих сегментов в дальнейшем началось наращивание модельной литосферы (рис. 8, в, г) в соответствии с моделью развития литосферного клина [Malkin, Shemenda, 1991; Shemenda, Grokholsky, 1994]. В процессе эксперимента развитие верхнего и среднего сегментов сопровождалось разнонаправленными перескоками оси спрединга, что привело к образованию крупного сдвига

Таблица 1. Значения основных параметров, принятых для моделирования трех сегментов Аденского хребта

Table 1. Main parameters for modeling of the three segments of the Aden ridge

\begin{tabular}{lccc}
\hline Параметры & \multicolumn{3}{c}{ Провинции } \\
\cline { 2 - 4 } & западная & центральная & восточная \\
\hline $\begin{array}{l}\text { Угол к направлению } \\
\text { растяжения, } \alpha^{0}\end{array}$ & $45-50$ & 50 & 70 \\
$\begin{array}{l}\text { Tолщина ослаблен- } \\
\text { ной зоны, } \mathrm{H}_{2} \text {, мм }\end{array}$ & 1 & 1 и 2 & 2 и 3 \\
\hline
\end{tabular}


(рис. 8, г). В это же время между средним и нижними сегментами перескоки оси спрединга в основном были однонаправленными, поэтому здесь расположены небольшие смещения, имеющие унаследованный характер от первоначального разрушения модели (рис. 8, б-г). Эксперимент показывает, что ширина ослабленной зоны влияет на их длину, а следовательно, и на их количество, так как границы ослабленной зоны ограничивают рост трещин. Интересно, что эксперимент показал картину разломов, схожую с той, что наблюдается в восточной провинции рассматриваемого района (см. рис. 7, в). Здесь рифтовая зона, протягивающаяся от тройного сочленения Оуэн до разлома Алула-Фартак, нарушена только одной крупной трансформной зоной Сокотра.

Центральный сегмент Аденского хребта был сформирован на континентальной литосфере на некотором удалении от Афарской горячей точки. Тем не менее ее влияние нельзя недооценивать. Центральная провинция в общем простирается под углом $50^{\circ}$ к генеральному направлению растяжения (см. рис. 7, б). На начальной стадии экспериментального моделирования

(a)

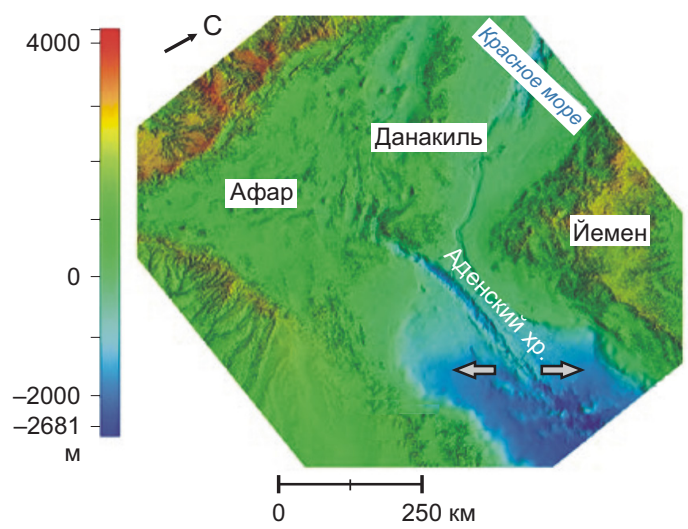

(б)

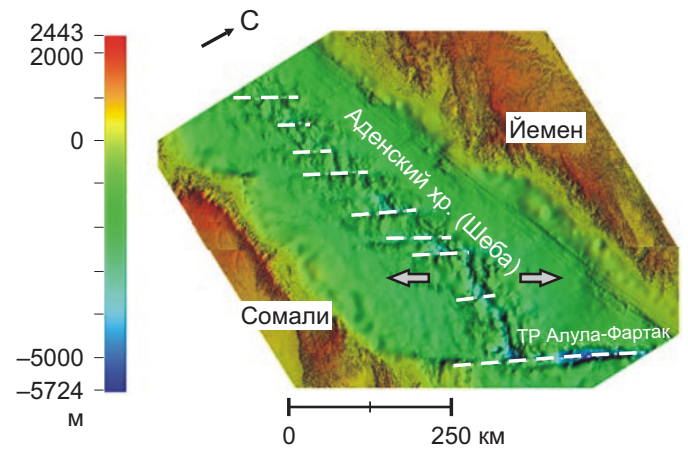

(в)

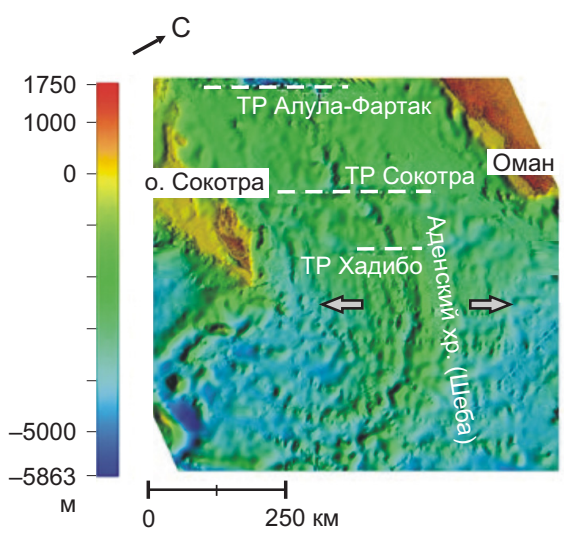

Рис. 7. Батиметрические карты различных сегментов Аденского хребта [The GEBCO_08 Grid, 2009].

(a) - западного сегмента, (б) - центрального сегмента, (в) - восточного сегмента (хребет Шеба). Ориентировка подобрана так, чтобы направления растяжения (показаны белыми стрелками) располагались горизонтально. Пунктирными линиями показаны трансформные смещения.

Fig.7. Bottom topography of different segments of the Aden ridge [The GEBCO_08 Grid, 2009].

$(a)$ - western segment, (б) - central segment, ( $($ ) - eastern segment (Sheba ridge). The orientation is chosen to horizontally arrange the spreading directions (shown by white arrows). Dashed lines - transform offsets. 
спрединга в центральной провинции (рис. 9, эксперимент 1451) формируется эшелон сегментов S-образной формы (рис. 9, а, б). В процессе дальнейшего растяжения образовавшиеся трещины соединились в одну и началось наращивание новой модельной литосферы (рис. 9, б, в). Стадия (в) на рис. 9 соответствует современной конфигурации центральной провинции Аденского залива (см. рис. 7, б). Здесь видны семь мелких сегментов, разделенных небольшими сдвиговыми смещениями трансформной природы. В то же время последняя стадия эксперимента может отражать будущую эволюцию рифтовой зоны центральной провинции Аденского залива (рис. 9, г). Эксперимент показывает, что увеличение угла наклона ослабленной зоны по отношению к генеральному направлению растяжения региона приводит к росту числа трещин и уменьшению их длины. Отметим, что на стадии (в) эксперимента наблюдается мелкая сегментация, характерная для современной центральной провинции Аденского залива.

Таким образом, эксперимент показывает, что при деформации зоны с косым рифтингом и с более тонкой прогретой литосферой начало процесса растяжения характеризуется формированием наклонного поля мелкой трещиноватости с ориентировкой трещин субортогонально направлению растяжения. Затем спрединг локализуется в нескольких более крупных трещинах, разделенных нетрансформными и трансформными смещениями, так что дальнейшая аккреция развивается вдоль них.

При экспериментальном моделировании спрединга в восточной и центральной провинциях на первых этапах развития рифтовой трещины формируются различные типы нетрансформных смещений оси, которые в дальнейшем либо исчезают, либо дают начало сдвигам, переходящим затем в трансформные разломы.

Особенностью западного сегмента является заметное термическое влияние на него близко расположенного Афарского плюма, а также относительная молодость сегмента, поэтому толщина модельной литосферы ослабленной рифтовой зоны в эксперименте была наименьшей из трех рассмотренных сегментов Аденского залива. Угол между простиранием рифта и направлением растяжения в этом районе был самым острым и в эксперименте 1463 составлял 45-50.

Разрушение модели в этом эксперименте началось с образования мелких эшелонированных S-образных

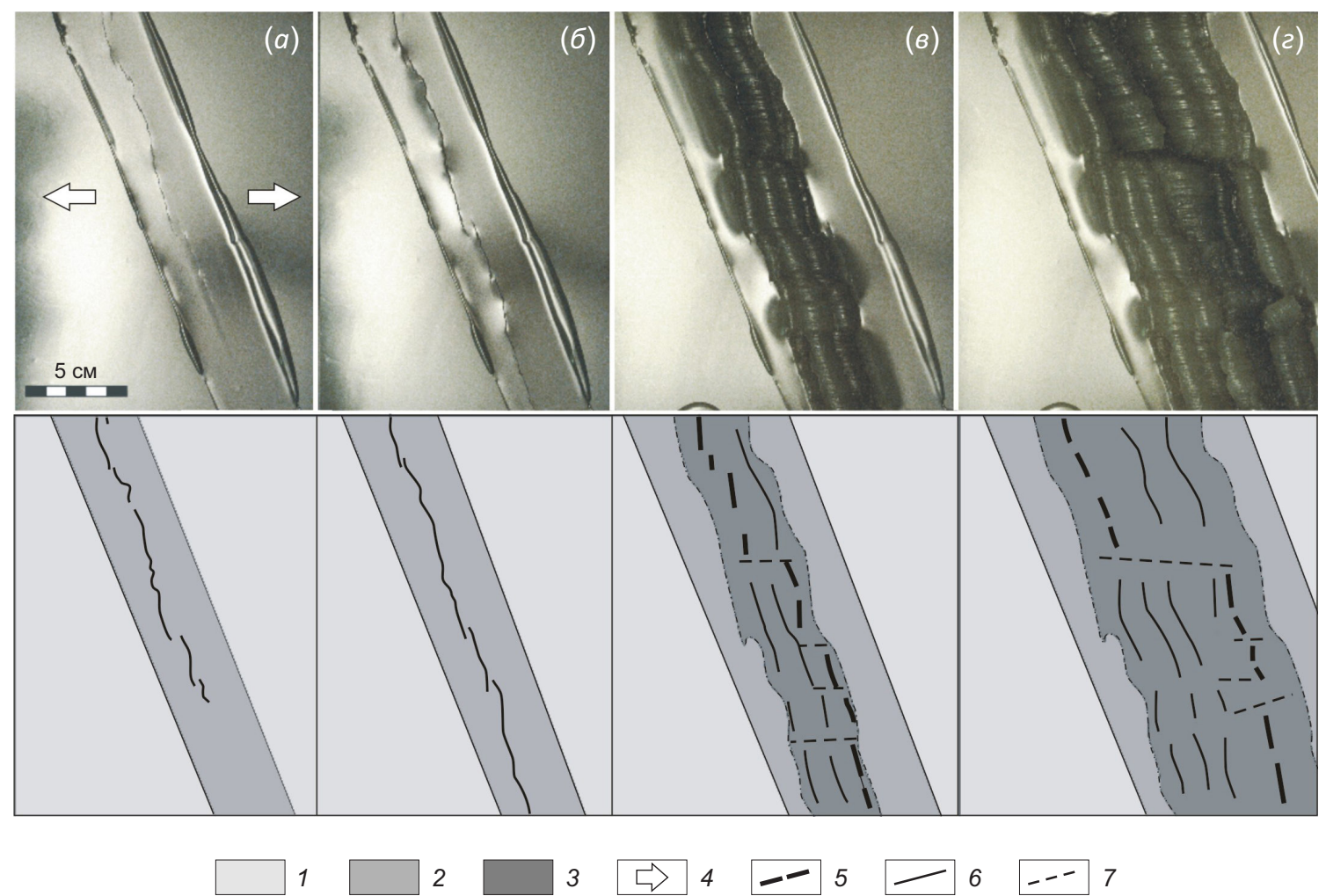

Рис. 8. Эксперимент 1447, иллюстрирующий структурообразование в восточной провинции.

$(a-2)$ - стадии эксперимента, внизу их дешифрирование. 1 - модельная плита; 2 - ослабленная зона (область прогрева рифта); 3 - вновь образованная модельная литосфера; 4 - направление растяжения; 5 - ось спрединга; 6 - отмершие оси спрединга, разделяющие поднятия; 7 - трансформные и нетрансформные смещения. $\mathrm{H}_{1}=4 \cdot 10^{-3} \mathrm{M} ; \mathrm{H}_{2}=2 \cdot 10^{-3} \mathrm{M} ; \mathrm{w}=4 \cdot 10^{-2} \mathrm{M} ; \mathrm{V}=1.87 \cdot 10^{-5} \mathrm{M} / \mathrm{c}^{-1}$; $\angle \alpha=70^{\circ}$.

Fig. 8. Structure formation model for the eastern province of the Gulf of Aden (experiment 1447).

$(a-2)$ - experiment stages; interpretations are given at the bottom. 1 - model plate; 2 - weakened (rift heating-up) zone; 3 - newly formed model lithosphere; 4 - stretching direction; 5 - spreading axis; 6 - dead spreading axes that separate elevations; 7 - transform and non-transform displacements. $\mathrm{H}_{1}=4 \cdot 10^{-3} \mathrm{~m} ; \mathrm{H}_{2}=2 \cdot 10^{-3} \mathrm{~m} ; \mathrm{w}=4 \cdot 10^{-2} \mathrm{~m} ; \mathrm{V}=1.87 \cdot 10^{-5} \mathrm{~m} / \mathrm{s}^{-1} ; \angle \alpha=70^{\circ}$. 
трещин (рис. 10, а), которые затем соединились и сформировали два длинных сегмента, разделенных нетрансформным смещением (рис. 10, б). Это смещение затем увеличилось в размерах и перешло в сдвиговый разлом (рис. 10, в, г). Однако при дальнейшем развитии эксперимента разлом уменьшается в размерах и затем исчезает. В результате формируется единый центр спрединга (рис. 10, г) и картина становится близкой к той, что мы наблюдаем в настоящее время в западной провинции Аденского залива, где спрединг идет вдоль единой оси, не прерываемой какими-либо крупными структурными нарушениями (см. рис. 7, а).

По результатам экспериментов можно сделать вывод о том, что решающее значение для сегментации имеют три параметра: толщина литосферы в ослабленной зоне, определяемая прогретостью литосферы, ширина и наклон зоны относительно направления растяжения. Так, при достаточно мощной литосфере в ослабленной зоне сегментация рифтовой трещины практически отсутствовала. При толщине модельной литосферы в ослабленной зоне в первые миллиметры сегменты трещин на начальной стадии имели средние размеры (1-2 см), в то время как толщина плиты в 1 мм соответствовала более пластичной деформации и здесь сегменты на ранних стадиях растяжения становились мельче (менее 1 см), так что в большинстве случаев они формировали практически единую ось спрединга.

Как отмечалось выше, угол между простиранием ослабленной зоны и направлением растяжения может заметно влиять на картину формирующихся разломов. На начальной стадии растяжения формируется эшелон из S-образных трещин, из которых в дальнейшем образуются сегменты оси спрединга, простирающиеся почти ортогонально к направлению растяжения. Эксперименты также показали, что картина сегментации постоянно меняется в процессе наращивания новой модельной коры. Одни сегменты исчезают, другие появляются, третьи оказываются долгоживущими в зависимости от условий их образования и развития.

Сходная история формирования разломов и трещин характерна как для других районов с косым растяжением и разной степенью прогретости литосферы (например, хребет Рейкьянес [Dubinin et al., 2011], Главный Эфиопский рифт [Agostini et al., 2009, 2011; Corti, 2012; Brune et al., 2017]), так и для экспериментов, проведенных ранее другими авторами для района Аденского залива, но с иными модельными материалами и методическими принципами моделирования [Agostini et al., 2009; Autin etal., 2010, 2013]. С помощью аналогового моделирования эти авторы детально исследовали развитие косого рифтинга в условиях дораскольных нарушений в континентальной литосфере в виде мезозойских грабенов, которые представляют собой структурные барьеры с более прочной, по сравнению с окружающей, литосферой на пути продвигающейся рифтовой трещины, давшей начало развитию бассейна Аденского залива. В качестве модельного вещества была использована смесь микросфер (4/5 стеклянные и 1/5 полые алюминиевые микросферы) и силиконовая масса как аналоги хрупкого и пластичного слоев соответственно. Чередование слоев позволяло создать хрупкопластичную 4-слойную модель мощной литосферы, наблюдаемой в кратонах, которая состоит из хрупкой верхней коры, пластичной нижней коры, хрупкой литосферной мантии и пластичной литосферной мантии. Моделируемая литосфера подстилалась пластичной крахмальной
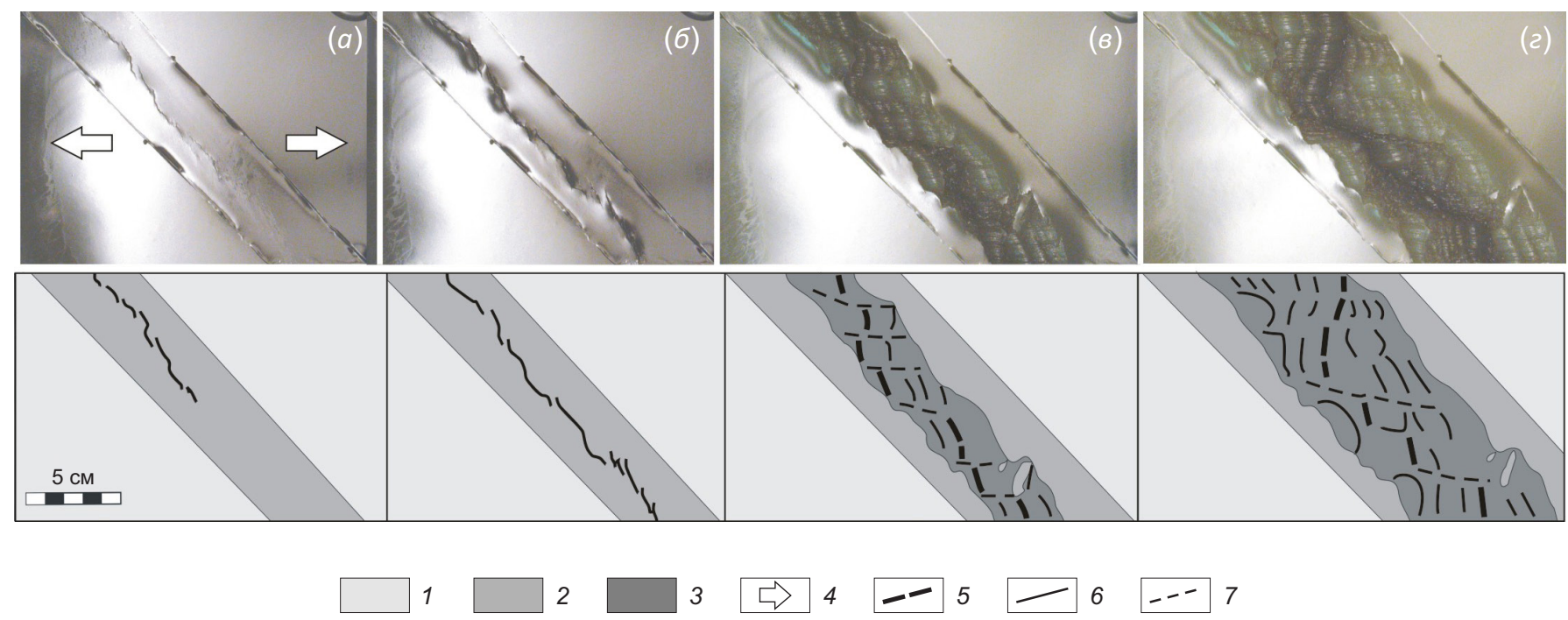

4

5

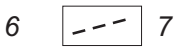

Рис. 9. Эксперимент 1451. Моделирование центрального сегмента Аденского залива.

$(a-2)$ - стадии эксперимента, внизу их дешифрирование. Условные обозначения см. на рис. $8 . \mathrm{H}_{1}=4 \cdot 10^{-3} \mathrm{M} ; \mathrm{H}_{2}=10^{-3} \mathrm{M}$; $\mathrm{w}=3 \cdot 10^{-2} \mathrm{M}$; $\mathrm{V}=1.87 \cdot 10^{-5} \mathrm{M} / \mathrm{c}^{-1} ; \angle \alpha=50^{\circ}$.

Fig. 9. Structure formation model for the central province of the Gulf of Aden (experiment 1451).

$(a-2)$ - experiment stages; interpretations are given at the bottom. $1-7-$ see the legend to Fig. $8 . \mathrm{H}_{1}=4 \cdot 10^{-3} \mathrm{~m} ; \mathrm{H}_{2}=10^{-3} \mathrm{~m} ; \mathrm{w}=3 \cdot 10^{-2} \mathrm{~m}$; $\mathrm{V}=1.87 \cdot 10^{-5} \mathrm{~m} / \mathrm{s}^{-1} ; \angle \alpha=50^{\circ}$. 
патокой, которая имитирует астеносферу. Вещество помещалось в бокс и подвергалось растяжению [Autin et al., 2010, 2013; Brune, Autin, 2013]. Результаты этого моделирования показали, что наследуемые грабены контролируют современную геометрию косого рифта и, в частности, локализацию главных структурных зон, которые делят Аденский залив на сегменты.

Сравнивая методологию нашего моделирования и французских исследователей, необходимо упомянуть два главных различия. Во-первых, смесь силикона и микросфер, использованная в вышеописанных экспериментах, позволяет моделировать хрупкий слой, имитирующий земную кору. В наших экспериментах слой земной коры не выделяется. Для моделирования структурообразования этого достаточно, но при наличии хрупкого слоя в коре четче прорисовывается рельеф. Второе существенное различие заключается в возможности моделирования влияния воздействия плюма или вариаций в степени прогретости мантии (толщина литосферы) на развивающуюся рифтовую систему. Это связано с тем, что в процессе всего эксперимента идет непрерывный подогрев вещества снизу, что приближает к процессу мантийной конвекции. Также есть возможность моделировать локальный прогрев (плюм или горячую точку), но в рамках данной работы подобные эксперименты не проводились.

\section{2. Экспериментальная серия 2. Соединение рифта Аденского залива со спрединговым хребтом Карлсберг и формирование краевого плато и острова Сокотра}

В этой серии экспериментов исследовались условия соединения континентального рифта, давшего начало раскрытию Аденского залива, с рифтом спредингового хребта Карлсберг. В связи с этим возникли следующие вопросы: 1) каким образом осуществляется соединение континентального и океанического рифтов в районе континентальной окраины? 2) представляют ли переходные зоны структурно-реологический барьер на пути продвигающегося рифта? 3) при каких условиях рифт может продвигаться в пределы континентальной литосферы из океанической? Аналогичная ситуация наблюдается в Калифорнийском заливе, где рифтовая зона Восточно-Тихоокеанского поднятия проникает в Калифорнийский залив и входит в пределы континента вдоль трансформного разлома Сан-Андреас.

Что касается восточной части Аденского залива, то мы не знаем, продвигались ли рифты только со стороны океана или два рифта со стороны континента и со стороны океана продвигались здесь навстречу друг другу.

В последнем случае в области перекрытия рифтов возможно формирование отторженных микроконтинентов в виде частично отделенных от материнского континента островов или погруженных краевых плато в пределах континентальных окраин. Таким образом могли формироваться краевое плато и остров Сокотра. Геодинамические обстановки формирования подобных структур рассмотрены в работе [Dubinin, 2018].

Первоначальная геометрия рифта была восстановлена по палеореконструкциям дорифтового положения Аравии и Африки (см. рис. 1 и 5). В экспериментах было рассмотрено несколько подходов.

\subsection{1. Взаимодействие трещин при наличии резкой границы между океаном и континентом}

В первоначальной постановке экспериментов предполагалось, что мощная континентальная литосфера Афро-Аравийского блока более прочная, чем океаническая. В модели в океаническом и континентальном
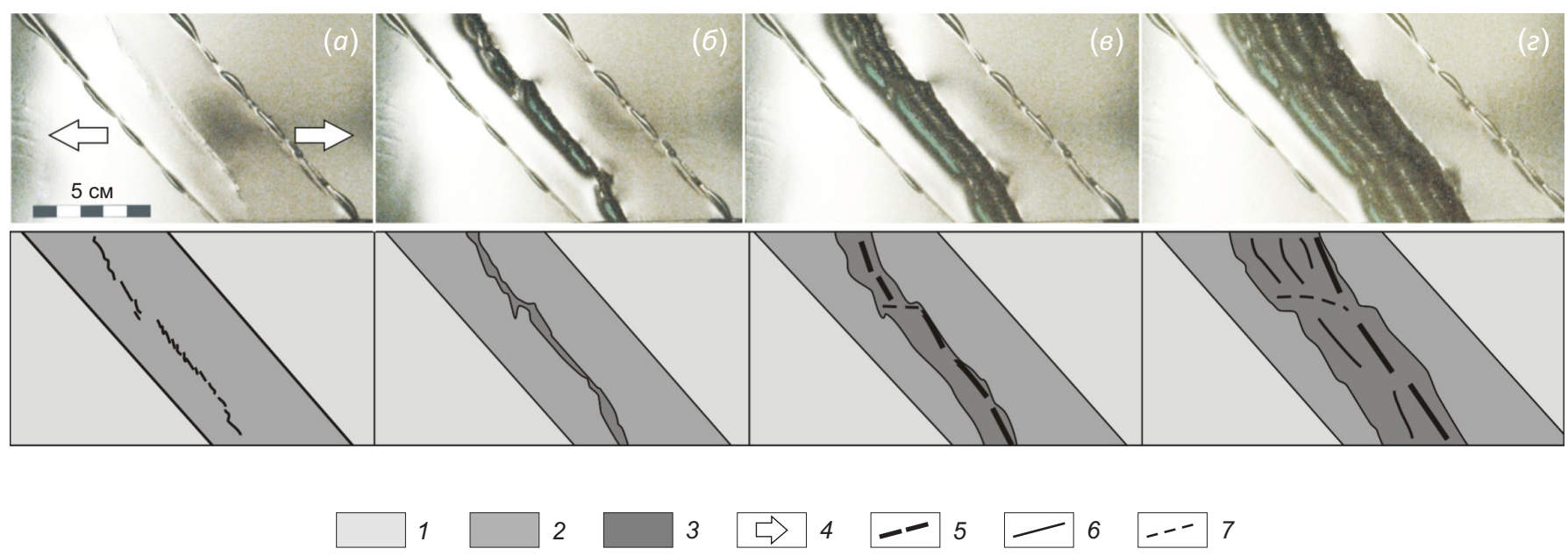
2 3 4 5

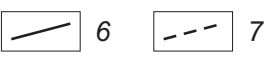

Рис. 10. Эксперимент 1463. Моделирование западного сегмента Аденского залива.

$(a-2)$ - стадии эксперимента, внизу их дешифрирование. Условные обозначения на $\mathrm{p} и с .8 . \mathrm{H}_{1}=4 \cdot 10^{-3} \mathrm{M} ; \mathrm{H}_{2}=10^{-3} \mathrm{M} ; \mathrm{w}=5 \cdot 10^{-2} \mathrm{M}$; $\mathrm{V}=1.87 \cdot 10^{-5} \mathrm{M} / \mathrm{c}^{-1} ; \angle \alpha=50^{\circ}$.

Fig. 10. Structure formation model for the western province of the Gulf of Aden (experiment 1463).

$(a-2)$ - experiment stages; interpretations are given at the bottom. $1-7-$ see the legend to $\mathrm{Fig} .8 \cdot \mathrm{H}_{1}=4 \cdot 10^{-3} \mathrm{~m} ; \mathrm{H}_{2}=10^{-3} \mathrm{~m} ; \mathrm{w}=5 \cdot 10^{-2} \mathrm{~m}$; $\mathrm{V}=1.87 \cdot 10^{-5} \mathrm{~m} / \mathrm{s}^{-1} ; \angle \alpha=50^{\circ}$. 
блоках было сделано по одному разрезу, имитирующему начальное положение рифта (рис. 11, а).

В экспериментах менялись мощности плит и длина разреза в океаническом блоке. В течение первых нескольких экспериментов было определено соотношение мощностей, при котором рост трещины начинается из разреза в океаническом блоке, что иллюстрирует ситуацию продвижения трещины из океана в континент. Для этого потребовалось охлаждать океанический блок до толщины не менее 4 мм. Также этому способствовало увеличение длины разреза в океанической коре.

Разрез в континентальном блоке был расположен под углом 50, что отражает общий тренд Аденской рифтовой зоны относительно направления растяжения.

Эксперимент 1477 (рис. 12) был подготовлен в соответствии со схемой (см. рис. 11, а). При такой конфигурации началось развитие трещины из разреза в нижнем («океаническом») блоке (рис. 12, б). Затем навстречу стала продвигаться трещина из разреза верхнего («континентального») блока. Обе трещины прошли границу океан - континент, которая в модели представляла линию раздела блоков литосферы с разной толщиной, затем незначительно перекрылись и остановились (рис. 12, в, г). После этого произошло их соединение по границе между блоками с образованием правостороннего сдвига, совпадающего с направлением растяжения (рис. 12 , в). На заключительных этапах эксперимента началось наращивание в модели новой коры (рис. 12, г).

Эксперименты этой подсерии позволяют сделать вывод о том, что на резкой границе между блоками разной прочности, вероятнее всего, возникнет сдвиговая зона. Эта ситуация применима к смещению рифтовых трещин и образованию трансформного разлома АлулаФартак (см. рис. 3).

\subsection{2. Взаимодействие трещины с неровной границей между океанической и континентальной литосферой}

До образования бассейна Аденского залива восточная окраина Афро-Аравийского континента контактировала через переходную зону с древней океанической литосферой Сомалийской котловины, отделенной с востока крупным трансформным разломом Оуэн от молодой коры, сформированной на продвигающемся в северо-западном направлении хребте Карлсберг. Зона контакта континент - океан не всегда прямолинейна. В данной подсерии экспериментов геометрия этой зоны задавалась не прямой границей, а искривленной (треугольной формы). Повышенная прочность континентального блока достигалась охлаждением его поверхности водой, а не различным временем охлаждения отдельных участков модельной плиты, как в предыдущей модели. Искривление границы континент - океан и косой разрез рифтовой трещины в континентальном (a)

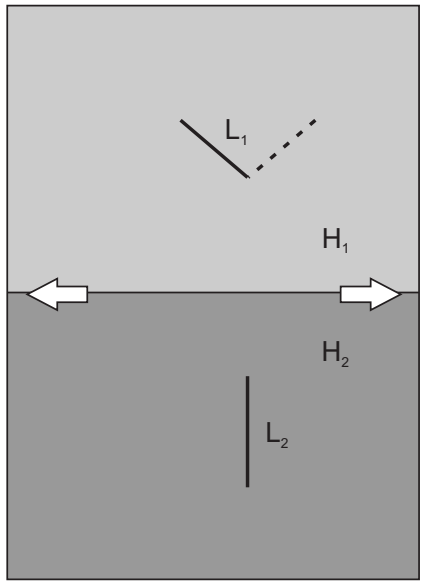

(б)

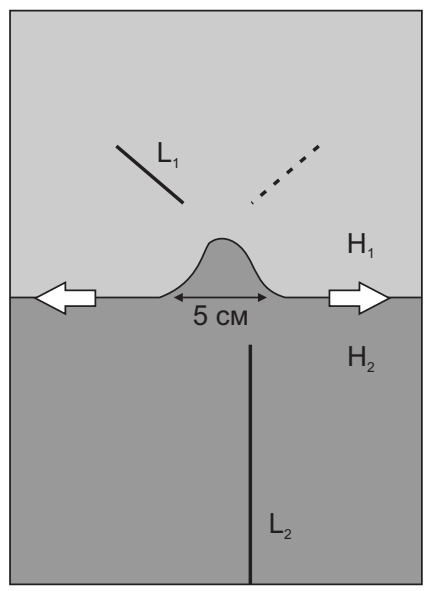

(b)

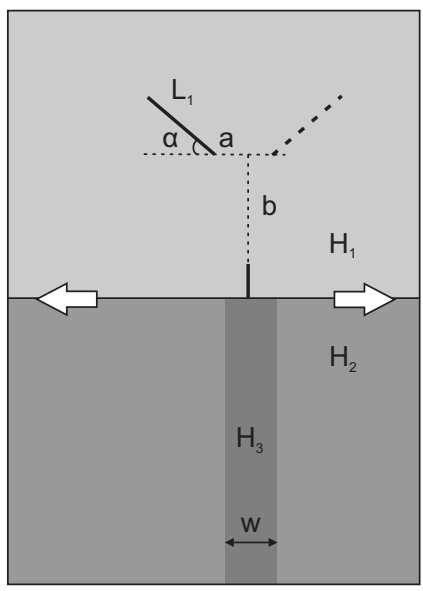

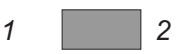

3
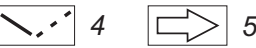

5

Рис. 11. Схема начальных условий экспериментов серии 2.

(a) - развитие рифтовых трещин при наличии двух разрезов в модельной «океанической» и «континентальной» литосфере;

(б) - развитие рифтовых трещин при неровной границе континент-океан; ( 8 ) - развитие рифтовых трещин при наличии ослабленной зоны в пределах океанической литосферы. $1-\mathrm{H}_{1}$ - толстая и прочная (континентальная) модельная плита; $2-\mathrm{H}_{2}$ - тонкая (океаническая) модельная плита; $3-\mathrm{H}_{3}$ - ослабленная зона (зона прогрева рифта) в океанической модельной литосфере; 4 - разрезы; 5 - направление растяжения. $\mathrm{L}_{1}$ и $\mathrm{L}_{2}$ - длина разрезов; a и $\mathrm{b}$ - величина поперечного и продольного смещения разрезов соответственно; $\angle \alpha$ - угол наклона разрезов; $\mathrm{W}$ - ширина ослабленной зоны.

Fig.11. Initial conditions of the experiments in series 2.

Development of rift faults in different models: $(a)$ - two cuts in oceanic and continental lithosphere; (б) - nonlinear continent-ocean boundary; $(8)$ - weakened zone within the oceanic lithosphere. $1-\mathrm{H}_{1}$ - thick and strong (continental) plate; $2-\mathrm{H}_{2}-$ thin (oceanic) plate; $3-\mathrm{H}_{3}$ - weakened (rift heating-up) zone in the oceanic lithosphere; 4 - cuts; 5 - stretching direction. $\mathrm{L}_{1}, \mathrm{~L}_{2}-$ lengths of the cuts; $\mathrm{a}, \mathrm{b}$ - transverse and longitudinal displacements of the cuts, respectively; $\angle \alpha$-inclination angles of the cuts. 
блоке повторяют задачи предыдущих экспериментов, то есть создают предпосылку для локализации начальных деформаций и встречного продвижения трещин (см. рис. 10, б).

Наиболее показательным экспериментом данной подсерии является эксперимент 1506 (рис. 13). Он был подготовлен в соответствии со схемой (см. рис. 11, б). $\mathrm{C}$ началом растяжения стала развиваться трещина из нижнего разреза в сторону треугольной границы блоков (рис. 13, а). Как только она достигла края границы, произошел ее перескок в центральную часть треугольника (рис. 13, б). В это же время стала продвигаться трещина из верхнего разреза. Она прошла через правую границу треугольника и сформировала перекрытие с трещиной в его центральной части (рис. 13, б). Образовался микроблок, вращающийся в процессе растяжения против часовой стрелки в горизонтальной плоскости, а также в вертикальной с поднятием его левого борта относительно правого. В верхней части он был ограничен сдвиговым разломом, субпараллельным

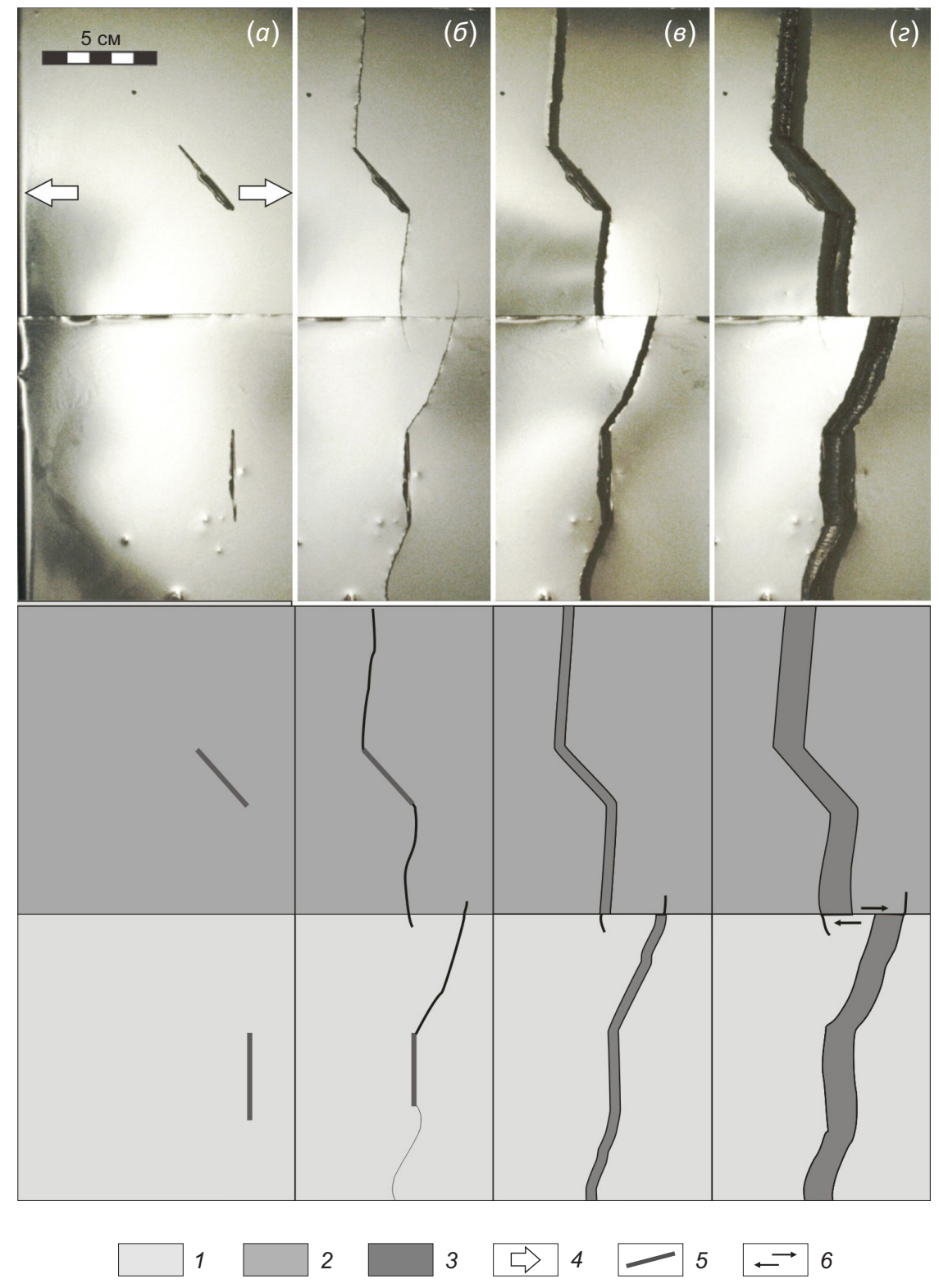

Рис. 12. Эксперимент 1477. Фото, вид сверху. Образование правостороннего сдвига на границе между океаном и континентом. $(a-2)$ - стадии эксперимента, внизу их дешифрирование. 1 - тонкая (океаническая) модельная плита; 2 - толстая и прочная (континентальная) модельная плита; 3 - вновь образованная модельная литосфера; 4 - направление растяжения; 5 - разрезы; 6 - направление сдвига. $\mathrm{H}_{1}=7 \cdot 10^{-3} \mathrm{M} ; \mathrm{H}_{2}=5 \cdot 10^{-3} \mathrm{M} ; \mathrm{L}_{1}=\mathrm{L}_{2}=4 \cdot 10^{-2} \mathrm{M} ; \mathrm{a}=0 ; \mathrm{b}=10^{-1} \mathrm{M} ; \angle \alpha_{\mathrm{L} 1}=50^{\circ} ; \mathrm{V}=1.87 \cdot 10^{-5} \mathrm{M} / \mathrm{c}^{-1}$.

Fig. 12. Formation of a right-lateral strike-slip fault at the boundary between the ocean and the continent (photo of experiment 1477, top view).

$(a-2)$ - experiment stages; interpretations are given at the bottom. 1 - thin (oceanic) plate; 2 - thick and strong (continental) plate; 3 - newly formed lithosphere; 4 - stretching direction; 5 - cuts; 6 - shift direction. $\mathrm{H}_{1}=7 \cdot 10^{-3} \mathrm{~m} ; \mathrm{H}_{2}=5 \cdot 10^{-3} \mathrm{~m} ; \mathrm{L}_{1}=\mathrm{L}_{2}=4 \cdot 10^{-2} \mathrm{~m} ; \mathrm{a}=0 ; \mathrm{b}=10^{-1}$ $\mathrm{m} ; \mathrm{V}=1.87 \cdot 10^{-5} \mathrm{~m} / \mathrm{s}^{-1} ; \angle \alpha_{\mathrm{L} 1}=50^{\circ}$. 
направлению растяжения (рис. 13, в). При дальнейшей аккреции новой модельной коры блок остался прикрепленным к левой части модельной плиты, в то время как правая спрединговая ветвь (аналог зарождающегося хребта Шеба) перекрытия стала активной (рис. 13, г). Заметим, что в модели в структуре микроблока присутствует как модельная океаническая, так и более толстая континентальная литосфера (рис. 13, в, г).

Эксперимент 1506 приближен к реальной природной ситуации в развитии восточной провинции. Можно предположить, что развитие правой ветви спрединга было усилено трещиной в континентальном блоке, заложенной перед началом эксперимента. Очевидно, что наличие ослабленной зоны (или трещины) в континентальном блоке имеет решающее значение, несмотря на первоначальное продвижение со стороны океана.

Также подобные эксперименты показывают, что в процессе своего продвижения трещина стремится перескочить в сторону менее прочного участка (в нашем случае - в сторону вершины треугольника) и если трещины будут развиваться по отдельности, то возможно формирование микроблоков между ними.
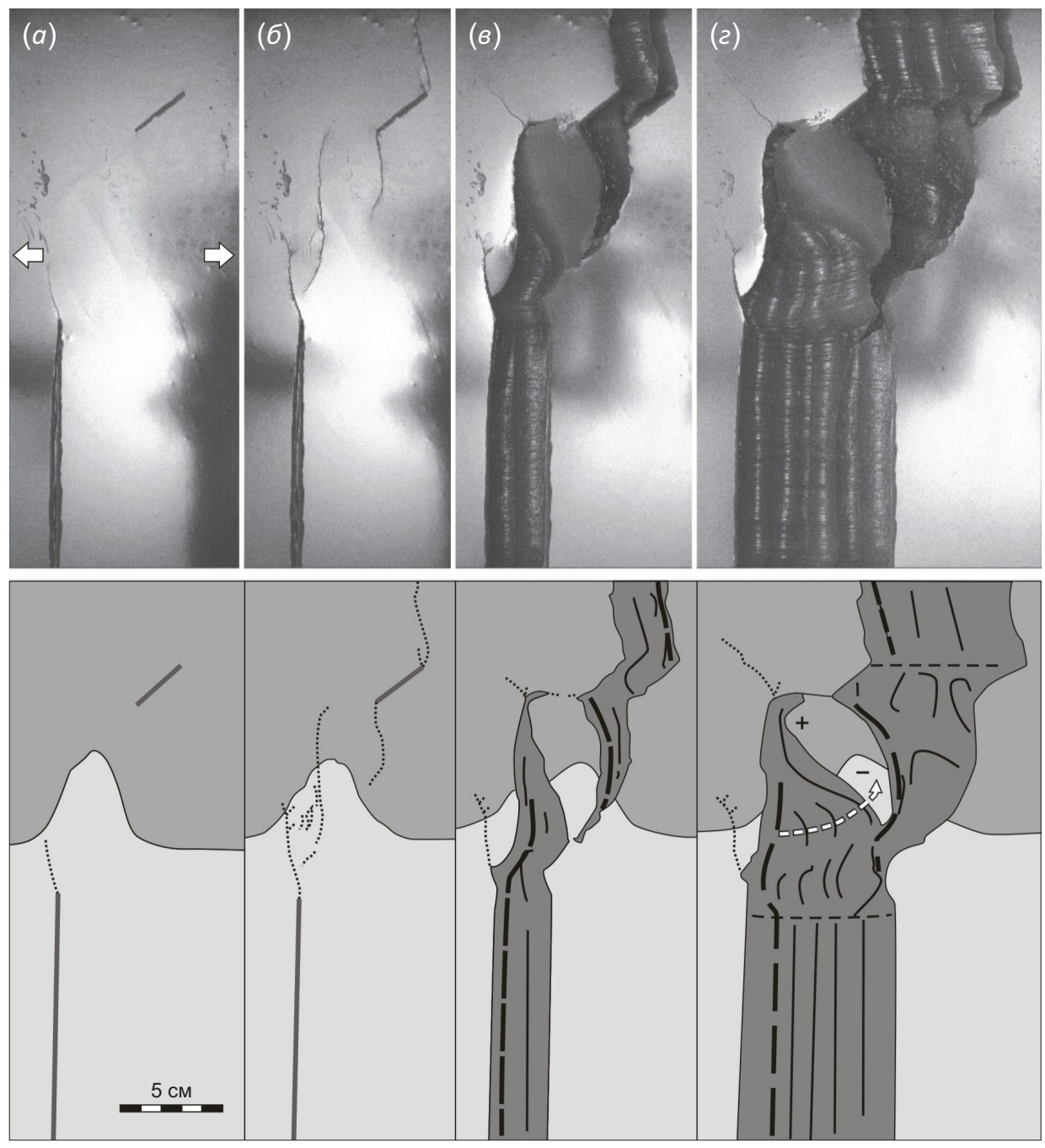

1 2 $3 \Rightarrow 4$
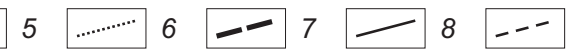

9

Рис. 13. Эксперимент 1506. Образование микроблока при неровной границе океана и континента.

$(a-2)$ - стадии эксперимента, внизу их дешифрирование. 1 - тонкая (океаническая) модельная плита; 2 - толстая и прочная (континентальная) модельная плита; 3 - вновь образованная модельная литосфера; 4 - направление растяжения; 5 - разрезы; 6 - траектории продвигающихся из разрезов трещин; 7 - ось спрединга; 8 - отмершие оси спрединга; 9 - трансформные и нетрансформные смещения; 10 - области поднятия и опускания; 11 - направление вращения блока. $\mathrm{H}_{1}=5 \cdot 10^{-3} \mathrm{M} ; \mathrm{H}_{2}=4 \cdot 10^{-3} \mathrm{M}$; $\mathrm{L}_{1}=2 \cdot 10^{-2} \mathrm{M} ; \mathrm{L}_{2}=10^{-1} \mathrm{M} ; \mathrm{a}=4 \cdot 10^{-2} \mathrm{M} ; \mathrm{b}=7 \cdot 10^{-2} \mathrm{M} ; \angle \alpha_{\mathrm{L} 1}=50^{\circ} ; \mathrm{V}=1.87 \cdot 10^{-5} \mathrm{M} / \mathrm{c}^{-1}$.

Fig. 13. Formation of a microblock in case of a rough ocean-continent boundary (experiment 1506).

$(a-2)$ - experiment stages; interpretations are given at the bottom. 1 - thin (oceanic) plate; 2 - thick and strong (continental) plate; 3 - newly formed lithosphere; 4 - stretching direction; 5 - cuts; 6 - trajectories of cracks advancing from the cuts; 7 - spreading axis; 8 - dead spreading axes; 9 - transform and non-transform displacements; 10 - uplifting and subsidence areas; 11 - direction of rotation of the block. $\mathrm{H}_{1}=5 \cdot 10^{-3} \mathrm{~m} ; \mathrm{H}_{2}=4 \cdot 10^{-3} \mathrm{~m} ; \mathrm{L}_{1}=2 \cdot 10^{-2} \mathrm{~m} ; \mathrm{L}_{2}=10^{-1} \mathrm{~m} ; \mathrm{a}=4 \cdot 10^{-2} \mathrm{~m} ; \mathrm{b}=7 \cdot 10^{-2} \mathrm{~m} ; \mathrm{V}=1.87 \cdot 10^{-5} \mathrm{~m} / \mathrm{s}^{-1} ; \angle \alpha_{\mathrm{L} 1}=50^{\circ}$. 


\subsection{3. Взаимодействие ослабленной зоны в океанической плите с континентальной рифтовой трещиной}

В экспериментах данной серии повышенная прочность континентального блока также достигалась охлаждением водой модельной литосферы сверху, а вместо разреза в океаническом блоке по всей его длине создавалась ослабленная зона (см. рис. 11, в). Верхняя граница ослабленной зоны совпадает с границей между блоками. Отсюда был сделан разрез, уходящий в континентальный блок. Так же, как и в предыдущих сериях, в континентальном блоке делался разрез, имитирующий рифтовую трещину в континенте под углом общего тренда рифта $50^{\circ}$.

В этих экспериментах основной изменяющийся параметр - расстояние между разрезами. Менялись и

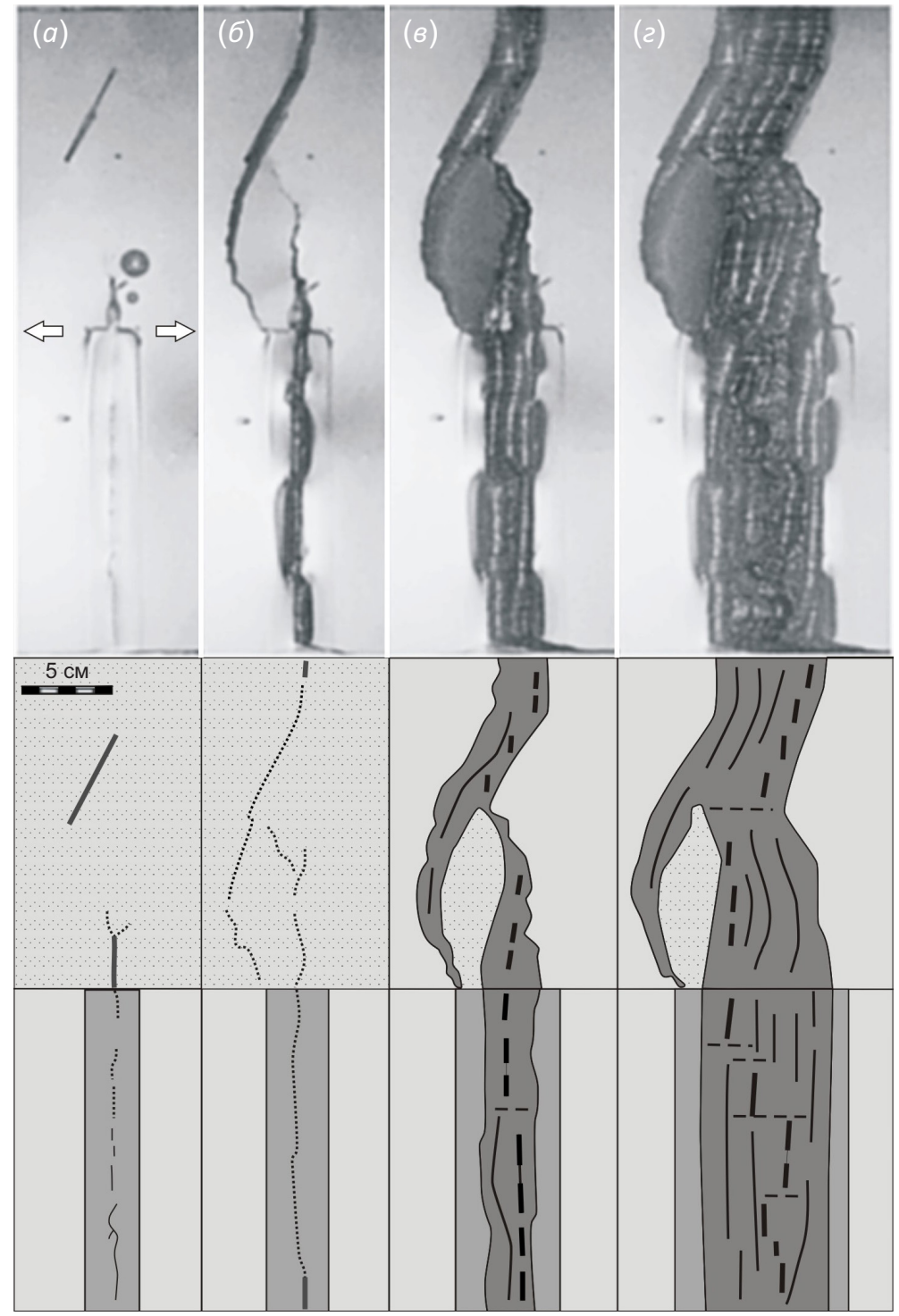

1

2

3

$4 \Rightarrow 5$

5

6

7

8

$9 \longdiv { - - } 1 0$

Рис. 14. Эксперимент 1541. Образование микроблока при взаимодействии двух трещин на ровной границе океан - континент. $(a-2)$ - стадии эксперимента, внизу их дешифрирование. 1 - толстая и прочная (континентальная) модельная плита; 2 - тонкая (океаническая) модельная плита; 3 - ослабленная (рифтовая) зона в океанической модельной литосфере; 4 - вновь образованная модельная литосфера; 5 - направление растяжения; 6 - разрезы; 7 - траектории продвигающихся из разрезов трещин; 8 - ось спрединга; 9 - отмершие оси спрединга; 10 - сдвиговые и нетрансформные смещения. $\mathrm{H}_{1}=4 \cdot 10^{-3} \mathrm{M} ; \mathrm{H}_{2}=3 \cdot 10^{-3} \mathrm{M}$ $\mathrm{H}_{3}=10^{-3} \mathrm{M} ; \mathrm{L}_{1}=4 \cdot 10^{-2} \mathrm{M} ; \mathrm{L}_{2}=2 \cdot 10^{-2} \mathrm{M} ; \mathrm{a}=5 \cdot 10^{-2} \mathrm{M} ; \mathrm{b}=2 \cdot 10^{-2} \mathrm{M} ; \mathrm{V}=2.5 \cdot 10^{-5} \mathrm{M} / \mathrm{c}^{-1} ; \angle \alpha=70^{\circ}$.

Fig. 14. Formation of a microblock in case of interaction of two cracks on the flat ocean-continent boundary (experiment 1541). $(a-2)$ - experiment stages; interpretations are given at the bottom. 1 - thick and strong (continental) plate; 2 - thin (oceanic) plate; 3 -weakened (rift) zone in the oceanic lithosphere; 4-newly formed lithosphere; 5 - stretching direction; 6 - cuts; 7 - trajectories of cracks advancing from the cuts; 8 - spreading axis; 9 - dead spreading axes; 10 - shift and non-transform displacements. $\mathrm{H}_{1}=4 \cdot 10^{-3} \mathrm{~m}$; $\mathrm{H}_{2}=3 \cdot 10^{-3} \mathrm{~m} ; \mathrm{H}_{3}=10^{-3} \mathrm{~m} ; \mathrm{L}_{1}=4 \cdot 10^{-2} \mathrm{~m} ; \mathrm{L}_{2}=2 \cdot 10^{-2} \mathrm{~m} ; \mathrm{a}=5 \cdot 10^{-2} \mathrm{~m} ; \mathrm{b}=2 \cdot 10^{-2} \mathrm{~m} ; \mathrm{V}=2.5 \cdot 10^{-5} \mathrm{~m} / \mathrm{s}^{-1} ; \angle \alpha=70^{\circ}$. 
размеры континентального и океанического блоков и длина разреза в континентальном блоке.

Были проведены опыты с различным расположением разрезов (включая угол их наклона) относительно друг друга или нанесенных вместо них в модельной литосфере ослабленных зон.

В большинстве случаев результатом экспериментов было формирование микроблока. Это достигалось при соблюдении оптимального продольного и поперечного расстояния между разрезами, которое составляло $3 \cdot 4$ см и $5 \cdot 2$ см.

В эксперименте 1541 была изменена геометрия разреза в континентальном блоке. Угол его наклона был $70^{\circ}$ относительно направления растяжения (рис. 14, а). В океанической части модели была сформирована ослабленная зона, продолжающаяся в континентальную часть в виде короткого разреза (см. рис. 11, в). С началом растяжения деформация стала развиваться в ослабленной зоне океанической части модельной плиты. Отсюда трещина продвигалась в континентальную часть через разрез на границе блоков (рис. 14, б). Сверху из наклонного разреза континентального блока также продвигалась трещина. Перекрывшись, трещины образовали микроблок с неровными границами и с вытянутой формой, нижняя часть которого проходила по границе континент - океан (рис. 14, б). Он испытывал небольшое вращение по часовой стрелке, а также в вертикальной плоскости. Затем перекрывшиеся трещины соединились в единую ось спрединга правее блока перекрытия (рис. 14, в). В процессе дальнейшего наращивания модельной литосферы блок испытывал вращение в вертикальной плоскости. Левый борт его при этом поднимался, а правый опускался (рис. 14, г). Сходную структуру имеет блок погруженного краевого плато и о. Сокотра.

Как и в опытах с неровной границей континент океан (см. раздел 5.2.2), в этих экспериментах отмечается решающее значение трещины, выходящей из континентального блока. Только при измененной геометрии, когда океанической трещине проще и быстрее дойти до ослабленной зоны в континенте, становится активной правая ветвь спрединга и картина становится похожей на исследуемый район плато и о. Сокотра.

В проведенных опытах следует отметить вращение блоков в вертикальной плоскости. Блок погруженного плато и о. Сокотра также имеет асимметричное строение: его восточная часть поднята над уровнем моря, а западная опущена.

Вращение блоков в горизонтальной плоскости - тоже важный экспериментальный факт. Простирания разломов на о. Сокотра свидетельствуют о том, что оси растяжения испытали вращение против часовой стрелки [Bellahsen et al., 2013b]. Вероятно, что и сам блок Сокотра испытывал вращение.

\section{6. ОБСУЖДЕНИЕ И ЗАКЛЮЧЕНИЕ}

Аденский залив - молодой рифтовый бассейн, подверженный в процессе своего развития влиянию разных факторов, определивших его современное тектоническое строение. Во-первых, изменение кинематики плит и ускорение движения Аравийской плиты относительно Африканской привело к формированию рифта, который развивался в пределах гетерогенной континентальной литосферы, осложненной мезозойскими грабенами. Во-вторых, располагающийся рядом Афарский плюм вызывал прогрев литосферы и создавал условия, благоприятные для рифтогенеза и образования спредингового хребта. В-третьих, рифтовая зона спредингового хребта Карлсберг, продвигающаяся со стороны Индийского океана в сторону Африкано-Аравийского материка, стремилась «замкнуть» границу между Индийской и Африканской плитами. Вероятно, все эти факторы внесли свой вклад в формирование бассейна Аденского залива.

Было рассмотрено развитие трех геодинамических провинций в Аденском заливе, выделенных ранее в работах [Bellahsen et al., 2013a; Brune, Autin, 2013; Leroy et al., 2010a]. Различие в морфоструктурной сегментации спредингового хребта отражает разный геодинамический режим формирования этих провинций. Часть восточного сегмента была сформирована на древней океанической литосфере, в то время как другая - на утоненной континентальной. Отрезки хребтов, сформированные на участках сегмента с однородной древней океанической литосферой, были ориентированы близко к нормали к направлению растяжения. Центральный сегмент образовался после временной остановки продвигающегося рифта в результате его столкновения со структурным барьером мезозойского грабена Джиза-Камар - Гвардафуй и последующего его смещения с образованием трансформного разлома АлулаФартак [Fournier et al., 2010]. Большое число трансформных разломов в пределах этого сектора говорит о приспособлении рифта к неоднородностям на его пути. Западный сегмент зоны спрединга Аденского залива находится под заметным влиянием Афарской горячей точки. Температура мантии здесь предположительно может достигать $1450{ }^{\circ} \mathrm{C}$ [Korostelev et al., 2015a]. Значительная прогретость литосферы способствует снижению мощности хрупкого слоя настолько, что затрудняет формирование трансформных разломов, образуются нетрансформные смещения. Вдольосевой мантийный поток, инициируемый Афарским плюмом, может влиять не только на сегментацию рифта, но и на его простирание: здесь рифт находится под самым острым углом к направлению растяжения (до 40-45).

С раскрытием Аденского залива связано образование погруженного плато и архипелага Сокотра, которые отделяются от Сомалийской плиты грабеном Гвардафуй. Можно полагать, что именно образование этого грабена способствовало окончательной изоляции архипелага Сокотра от Африканского материка [Bellahsen et al., 2013b]. При формировании о. Сокотра в процессе растяжения имели место деформации, связанные с его вращением, которые отражаются в различном тектоническом строении западной и восточной части острова. 
Было проведено физическое моделирование по двум сериям экспериментов, в одной из которых изучалась сегментация рифтовой трещины Аденского хребта при разных кинематических режимах спрединга, а во второй проводилось исследование условий соединения континентального рифта Аденского залива с рифтовой зоной спредингового хребта Карлсберг.

Результаты первой экспериментальной серии показали, что характер морфоструктурной сегментации оси спрединга в районе Аденского залива зависит, прежде всего, от степени прогретости и толщины литосферы, связанной с разной удаленностью изучаемых сегментов от Афарского плюма. Важность этого фактора отмечалась ранее в работе [Bellahsen et al., 2013a]. Влияние на сегментацию оказывает ориентация спрединговой оси по отношению к региональному направлению растяжения, а также наличие структурных неоднородностей с повышенной прочностью литосферы, обусловленных присутствием на дораскольном фундаменте серии мезозойских грабенов. Уменьшение мощности литосферы или/и угла между простираниями ослабленной зоны и осью растяжения приводит к усилению сегментации. Эксперимент показывает, что на начальной стадии растяжения формируется эшелон из S-образных трещин без трансформных смещений, а затем развиваются сегменты оси спрединга, стремящиеся к положению, ортогональному направлению растяжения. По всей видимости, именно мезозойские грабены с их более прочной литосферой повлияли на изначальную геометрию рифтовой трещины, ее сегментацию и формирование трансформных разломов в центральном сегменте Аденского залива. Результаты этой серии экспериментов в целом подтверждают результаты аналогового [Autin et al., 2010, 2013] и численного [Brune, Autin, 2013; Bellahsen et al., 2013а] моделирования структурообразующих деформаций и закономерности распределения разломов и грабенов в Аденском заливе, установленные при косом рифтинге и при наличии структурных неоднородностей в дораскольной литосфере.

Исследование условий соединения континентального рифта Аденского залива с рифтовой зоной спредингового хребта Карлсберг касается проблемы преодоления рифтовой трещиной «структурных барьеров». По всей видимости, в данном случае соединение континентального и океанического рифта осуществлялось посредством их продвижения навстречу друг другу. Эксперименты этой серии предполагают, что в случае «резкой» границы между блоками разной толщины (прочности), вероятнее всего, возникнет сдвиговая зона, аналогичная наблюдаемой в ТР Алула-Фартак или ТР Оуэн. Однако в случае менее «резкой» границы часто формируются структуры перекрытия, представляющие собой микроплиты, или микроблоки, заключенные между двумя рифтами, один из которых в дальнейшем отмирает, а другой развивается в спрединговый хребет. Таким микроблоком, видимо, является погруженное плато и о. Сокотра. Как показало моделирование, при формировании краевого плато и о. Сокотра важную роль играет встречное продвижение двух рифтов при существенной роли их первоначальной геометрии и величины смещения относительно друг друга.

Таким образом, реологическая стратификация литосферы и степень прогретости мантии, а также гетерогенное строение дораскольной литосферы, изначальная геометрия рифтовых зон и угол между направлением растяжения и простиранием рифта являются основными факторами, определяющими характер раскола континентальной литосферы, морфоструктурную сегментацию оси спрединга, асимметричное строение континентальных окраин и условия формирования погруженных континентальных плато.

\section{7. БЛАГОДАРНОСТИ}

Авторы выражают свою признательность уважаемым рецензентам за конструктивные предложения и советы. Авторы также благодарны А.Н. Филаретовой за помощь в оформлении рукописи.

\section{8. ЛИТЕРАТУРА / REFERENCES}

Agostini A., Bonini M., Corti G., Sani F., Mazzarini F., 2011. Fault Architecture in the Main Ethiopian Rift and Comparison with Experimental Models: Implications for Rift Evolution and Nubia-Somalia Kinematics. Earth and Planetary Science Letters 301 (3-4), 479-492. https://doi.org/10. 1016/j.epsl.2010.11.024.

Agostini A., Corti G., Zeoli A., Mulugeta G., 2009. Evolution, Pattern, and Partitioning of Deformation during Oblique Continental Rifting: Inferences from Lithospheric-Scalecentrifuge Models. Geochemistry, Geophysics, Geosystems 10 (11), 23. https://doi.org/10.1029/2009GC002676.

Allemand P., Brun J.-P., 1991. Width of Continental Rifts and Rtheological Layering of the Lithosphere. In: P.R. Cobbold (Ed.), Experimental and Numerical Modelling of Continental Deformation. Tectonophysics 188 (1-2), 63-69. https: / doi. org/10.1016/0040-1951(91)90314-I.

Autin J., Bellahsen N., Husson L., Beslier M.-O., Leroy S., d'Acremont E., 2010. Analog Models of Oblique Rifting in a Cold Lithosphere. Tectonics 29 (6), TC6016. http://dx.doi. org/10.1029/2010TC002671.

Autin J., Bellahsen N., Leroy S., Husson L., Beslier M.-O., d'Acremont E., 2013. The Role of Structural Inheritance in Oblique Rifting: Insights from Analogue Models and Application to the Gulf of Aden. Tectonophysics 607, 51-64. https://doi.org/10.1016/j.tecto.2013.05.041.

Bellahsen N., Husson L., Autin J., Leroy S., d'Acremont E., 2013a. The Effect of Thermal Weakening and Buoyancy Forces on Rift Localization: Field Evidences from the Gulf of Aden Oblique Rifting. Tectonophysics 607, 80-97. https:// doi.org/10.1016/j.tecto.2013.05.042.

Bellahsen N., Leroy S., Autin J., Razin P., d'Acremont E., Sloan H., Pik R., Ahmed A., 2013b. Pre-Existing Oblique Transfer Zones and Transfer/Transform Relationships in Continental Margins: New Insights from the Southeastern Gulf of Aden, Socotra Island, Yemen. Tectonophysics 607, 32-50. https://doi.org/10.1016/j.tecto.2013.07.036. 
Belousov V.V., Gzovsky M.V., 1964. Experimental Tectonics. Nedra, Moscow, 118 p. (in Russian) [Белоусов B.В., Гзовский М.В. Экспериментальная тектоника. 1964. М.: Недра, 118 с.].

Birse A.C.R., Bott W.F., Morrison J., Samuel M.A., 1997. The Mesozoic and Early Tertiary Tectonic Evolution of the Socotra Area, Eastern Gulf of Aden, Yemen. Marine and Petroleum Geology 14 (6), 675-684. https://doi.org/10.1016/ S0264-8172(96)00043-8.

Bonini M., Souriot T., Boccaletti M., Brun P., 1997. Successive Orthogonal and Oblique Exrension Episodes in a Rift Zone: Laboratory Experiments with Application to the Ethiopian Rift. Tectonics 16 (2), 347-362. https://doi.org/ 10.1029/96TC03935.

Bornyakov S.A., Seminsky K.Zh., Buddo V.Yu., Miroshnichenko A.I., Cheremnykh A.V., Cheremnykh A.S., Tarasova A.A., 2014. Main Regularities of Faulting in Lithosphere and Their Application (Based on Physical Modelling Results). Geodynamics \& Tectonophysics 5 (4), 823-861 (in Russian) [Борняков С.А., Семинский К.Ж., Буддо В.Ю., Мирошниченко А.И., Черемных А.В., Черемных А.С., Тарасова А.А. Основные закономерности разломообразования в литосфере и их прикладные следствия (по результатам физического моделирования). Геодинамика и тектонофизика. 2014. T. 5. №. 4. C. 823-861]. https://doi.org/10.5800/GT2014-5-4-0159.

Bosworth W., Huchon P., McClay K., 2005. The Red Sea and Gulf of Aden Basins. Journal of African Earth Sciences 43 (1-3), 334-378. https://doi.org/10.1016/j.jafrearsci. 2005.07.020.

Bosworth W., Huchon P., McClay K., 2012. The Red Sea and Gulf of Aden Basins. Phanerozoic Passive Margins, Cratonic Basins and Global Tectonic Maps 62-139. https://doi. org/10.1016/B978-0-444-56357-6.00003-2.

Brune S., Autin J., 2013. The Rift to Break-up Evolution of the Gulf of Aden: Insights from 3D Numerical Lithospheric - Scale Modeling. Tectonophysics 607, 65-79. https://doi. org/10.1016/j.tecto.2013.06.029.

Brune S., Corti G., Ranalli G., 2017. Controls of Inherited Lithospheric Heterogeneity on Rift Linkage: Numerical and Analog Models of Interaction between the Kenyan and Ethiopian Rifts across the Turkana Depression. Tectonics 36 (9), 1767-1786. https://doi.org/10.1002/2017TC0 04739.

Corti G., 2012. Evolution and Characteristics of Continental Rifting: Analog Modeling Inspired View and Comparison with Examples from the East African Rift System. Tectonophysics 522-523, 1-33. http://dx.doi.org/10.1016/j. tecto.2011.06.010.

Corti G., Calignano E., Petit C., Sani F., 2011. Controls of Lithospheric Structure and Plate Kinematics on Rift Architecture and Evolution: An Experimental Modeling of the Baikal Rift. Tectonics 30 (3), TC3011. http://dx.doi.org/ 10.1029/2011TC002871.

Corti G., Manetti P., 2006. Asymmetric Rifts Due to Asymmetric Mohos: An Experimental Approach. Earth Planetary Science Letters 245 (1-2), 315-329. https://doi.org/10. 1016/j.epsl.2006.02.004.
Corti G., Ranalli G., Agostini A., Sokoutis D., 2013. Inward Migration of Faulting during Continental Rifting: Effects of Pre-existing Lithospheric Structure and Extension Rate. Tectonophysics 594, 137-148 http://dx.doi.org/10.1016/j.tecto. 2013.03.028.

Corti G., van Wijk J., Cloetingh S., Morley C.K., 2007. Tectonic Inheritance and Continental Rift Architecture: Numerical and Analogue Models of the East African Rift System. Tectonics 26 (6), TC6006. http://dx.doi.org/10.1029/2006 TC002086.

D’Acremont E., Leroy S., Beslier M., Bellahsen N., Fournier M., Robin C., Maia M., Gente P., 2005. Structure and Evolution of the Eastern Gulf of Aden Conjugate Margins from Seismic Reflection Data. Geophysical Journal International 160 (3), 869-890. https://doi.org/10.1111/j.1365-246X. 2005.02524.x.

D’Acremont E., Leroy S., Beslier M., Bellahsen N., Fournier M., Robin C., Maia M., Gente P., 2006. Structure and Evolution of the Eastern Gulf of Aden: Insights from Magnetic and Gravity Data (Encens-Sheba MD117 Cruise). Geophysical Journal International 165 (3), 786-803. https: / /doi.org/ 10.1111/j.1365-246X.2006.02950.x.

D’Acremont E., Leroy S., Maia M., Gente P., Autin J., 2010. Volcanism, Jump and Propagation on the Sheba Ridge, Eastern Gulf of Aden: Segmentation Evolution and Implications for Oceanic Accretion Processes. Geophysical Journal International 180 (2), 535-551. https://doi.org/10.1111/j.1365246X.2009.04448.x.

Dauteuil O., Bourgeois O., Mauduit T., 2002. Lithosphere Strength Controls Oceanic Transform Zone Structure: Insights from Analogue Models. Geophysical Journal International 150 (3), 706-714. https://doi.org/10.1046/j.1365246X.2002.01736.x.

Dauteuil O., Huchon P., Quemeneur F., Souriot T., 2001. Propagation of an Oblique Spreading Centre: The Western Gulf of Aden. Tectonophysics 332 (4), 423-442. https:// doi.org/10.1016/S0040-1951(00)00295-X.

Dauteuil O., Mart Y., 1998. Analogue Modeling of Faulting Pattern, Ductile Deformation, and Vertical Motion in Strike-Slip Fault Zones. Tectonics 17 (20), 303-310. https:// doi.org/10.1029/97TC03410.

Dooley T.P., Schreurs G., 2012. Analogue Modelling of Intraplate Strike-Slip Tectonics: A Review and New Experimental Results. Tectonophysics 574-575, 1-71. https://doi. org/10.1016/j.tecto.2012.05.030.

Dubinin E.P., 2018. Geodynamic Setting of the Formation of Microcontinents, Submerged Plateaus, and Nonvolcanic Islands within Continental Margins. Oceanology 58 (3), 435446. https://doi.org/10.1134/S0001437018030062.

Dubinin E.P., Galushkin Yu.I., Grokholskii A.L., Kokhan A.V., Sushchevskaya N.M., 2017. Hot and Cold Zones of the Southeast Indian Ridge and Their Influence on the Peculiarities of Its Structure and Magmatism (Numerical and Physical Modelling). Geotectonics 51, 209-229. https://doi.org/10. 1134/S0016852117030049.

Dubinin E.P., Grokholskii A.L., Kokhan A.V., Sveshnikov A.A, 2011. Thermal and Rheological State of the Lithosphere and Specific Features of Structuring in the Rift Zone of the 
Reykjanes Ridge (from the Results of Numerical and Experimental Modeling). Izvestiya, Physics of the Solid Earth 47, 586-599. https://doi.org/10.1134/S1069351311060036.

Dubinin E.P., Kokhan A.V., Teterin D.E., Grokholsky A.L., Kurbatova E.S., Sushchevskaya N.M., 2016. Tectonics and Types of Riftogenic Basins of the Scotia Sea, South Atlantic. Geotectonics 50 (1), 35-53. https://doi.org/10.1134/S00 16852116010039.

Dubinin E.P., Ushakov S.A., 2001. Oceanic Riftogenesis. GEOS, Moscow, 292 p. (in Russian) [Дубинин Е.П., Ушаков C.A. Океанический рифтогенез. 2001. М.: ГЕОС, 292 с.]

Fournier M., Chamot-Rooke N., Petit C., Huchon Ph., AlKathiri A., Audin L., Beslier M-O., d'Acremont E., Fabbri O., Fleury J.-M., Khanbari Kh., Lepvrier C., Leroy S., Maillot B., Merkouriev S., 2010. Arabia-Somalia Plate Kinematics, Evolution of the Aden-Owen-Carlsberg Triple Junction, and Opening of the Gulf of Aden. Journal of Geophysical Research: Solid Earth 115 (B4), B04102. https://doi.org/10. 1029/2008JB006257.

Fournier M., Huchon Ph., Khanbari Kh., Leroy S., 2007. Segmentation and Along-Strike Asymmetry of the Passive Margin in Socotra, Eastern Gulf of Aden: Are They Controlled by Detachment Faults? Geochemistry, Geophysics, Geosystems 8 (3), Q03007. https://doi.org/10.1029/2006 GC001526.

Gerya T., 2012. Origin and Models of Oceanic Transform Faults. Tectonophysics 522-523, 34-54. https://doi.org/ 10.1016/j.tecto.2011.07.006.

Goncharov M.A., Talitsky V.G., Frolova N.S., 2005. Introduction to Tectonophysics. Book House «University», Moscow, 496 p. (in Russian) [Гончаров М.А., Талицкий В.Г., Фролова Н.С. Введение в тектонофизику. М.: Книжный дом «Университет», 2005. 496 с.].

Grokholskii A.L., Dubinin E.P., 2006. Experimental Modeling of Structure-Forming Deformations in Rift Zones of MidOcean Ridges. Geotectonics 40, 64-80. https://doi.org/10. 1134/S0016852106010067.

Grokholskii A.L., Dubinin E.P., 2010. Structure Formation in the Rift Zones and in Transvers Offset of the Spreading Axes: Results of Physical Modeling. Izvestiya, Physics of the Solid Earth 46, 49-55. https://doi.org/10.1134/S1 06935131005006X.

Grokholsky A.L., Dubinin E.P. Kokhan A.V., Petrova A.V., 2014. Off Axis Structures of Spreading Zones According to Results of Experimental Modeling. Geotectonics 48, 87-103. https://doi.org/10.1134/S0016852114020034.

Gzovsky M.V., 1975. Fundamentals of Tectonophysics. Nauka, Moscow, 536 p. (in Russian) [Гзовский М.B. Основы тектонофизики. М.: Наука, 1975. 536 с.].

Huchon P., Khanbari K., 2003. Rotation of the Syn-Rift Stress Field of the Northern Gulf of Aden Margin, Yemen. Tectonophysics 364, 147-166. https://doi.org/10.1016/ S0040-1951(03)00056-8.

Keep M., McClay K.R., 1997. Analogue Modeling of Multiphase Rift System. Tectonophysics 273 (3-4), 239-270. https://doi.org/10.1016/S0040-1951(96)00272-7.

Kokhan A.V., Dubinin E.P., Grokholsky A.L., Abramova A.S., 2012. Kinematics and characteristic features of the Knipovich
Ridge. Oceanology 52, 688-699. https://doi.org/10.1134/ S0001437012050098.

Konstantinovskaya E.A., Harris L.B., Poulin J., Ivanov G.M., 2007. Transfer Zones and Fault Reactivation in Inverted Rift Basins: Insights from Physical Modeling. Tectonophysics 441 (1-4), 1-26. https://doi.org/10.1016/j.tecto.2007.06.002.

Korostelev F., Leroy S., Keir D., Ahmed A., Boschi L., Rolandone F., Stuart G.W., Obrebski M., Khanbari Kh., El-Hussain I., 2015a. Upper Mantle Structure of the Southern Arabian Margin: Insights from Teleseismic Tomography. Geosphere 11 (5), 1262-1278. https://doi.org/10.1130/GES01159.1.

Korostelev F., Leroy S., Keir D., Weemstra C., Boschi L., Molinari I., Ahmed A., Stuart G.W., Rolandone F., Khanbari Kh., Al-Lazki A., 2015b. Magmatism at Continental Passive Margins Inferred from Ambient-Noise Phase-Velocity in the Gulf of Aden. Terra Nova 28 (1), 19-26. https://doi.org/10. 1111/ter.12182.

Leroy S., d'Acremont E., Tiberi C., Basuyau C., Autin J., Lucazeau F., Sloan H., 2010a. Recent Off-Axis Volcanism in the Eastern Gulf of Aden: Implications for Plume-Ridge Interaction. Earth and Planetary Science Letters 293 (1-2), 140-153. https://doi.org/10.1016/j.epsl.2010.02.036.

Leroy S., Lucazeau F., d'Acremont E., Watremez L., Autin J., Rouzo S., Bellahsen N., Tiberi C., 2010b. Contrasted Styles of Rifting in the Eastern Gulf of Aden: A Combined WiDe-angle, Multichannel Seismic, and Heat Flow Survey. Geochemistry, Geophysics, Geosystems 11 (Q07004), 1-14. http://dx.doi. org/10.1029/2009GC002963.

Leroy S., Razin Ph., Autin J., Bache F., d'Acremont E., Watremez L., Robinet J., Baurion C., 2012. From Rifting to Oceanic Spreading in the Gulf of Aden: A Synthesis. Arabian Journal of Geosciences 5, 859-901. http://dx.doi.org/10.1007/s1 2517-011-0475-4.

Logachev N.A., Bornyakov S.A., Sherman S.I., 2000. On the Mechanism of Formation of the Baikal Rift Zone Based on the Results of Physical Modeling. Doklady Earth Sciences 373 (3), 388-390 (in Russian) [Логачев Н.А., Борняков С.А., Шерман С.И. О механизме формирования Байкальской рифтовой зоны по результатам физического моделирования // Доклады АН. 2000. Т. 373. № 3. С. 388-390].

Lukashov A.A., 2013. The Morphostructural Evolution of the Gulf of Aden Southern Margin. Geomorphology 1, 35-43 (in Russian) [Лукашов А.А. Морфоструктурная эволюция южного фланга Аденского рифта // Геоморфология. 2013. №. 1. С. 35-43].

Malkin B.V., Shemenda A.I., 1991. Mechanism of Rifting: Considerations Based on Results of Physical Modelling and on Geological and Geophysical Data. Tectonophysics 199 (2-4), 193-210. https://doi.org/10.1016/0040-1951(91) 90172-0.

Mart Y., Dauteuil O., 2000. Analogue Experiment of Propagation of Oblique Rifts. Tectonophysics 316 (1-2), 121-132. https://doi.org/10.1016/S0040-1951(99)00231-0.

Mauduit T., Dauteuil O., 1996. Small-Scale Models of Oceanic Transform Zones. Journal Geophysical Research 101 (B9). https://doi.org/10.1029/96JB01509.

Maus S., Barckhausen U., Berkenbosch H., Bournas N., Brozena J., Childers V., Dostaler F., Fairhead J.D. et al., 2009. 
EMAG2: A 2- Arc Min Resolution Earth Magnetic Anomaly Grid Compiled from Satellite, Air-Borne, and Marine Magnetic Measurements. Geochemistry, Geophysics, Geosystems 10 (8), Q08005. https://doi.org/10.1029/2009GC002471.

McClay K., Ellis P., 1987. Geometries of Extensional Fault System Developed in Model Experiments. Geology 15 (4), 341-344. https://doi.org/10.1130/0091-7613(1987)15 \%3C341:GOEFSD\%3E2.0.CO;2.

McClay K.R., Dooley T., Whitehouse P., Mills M., 2002. 4-D Evolution of Rift Systems: Insights from Scaled Physical Models. AAPG Bulletin 86 (6), 935-959. https://doi.org/ 10.1306/61EEDBF2-173E-11D7-8645000102C1865D.

Michon L., Merle O., 2003. Mode of Lithospheric Extension: Conceptual Models from Analogue Modeling. Tectonics 22 (4), 1028. https://doi.org/10.1029/2002TC001435.

Molnar N.E., Cruden A.R., Betts P.G., 2017. Interactions between Propagating Rotational Rifts and Linear Rheological Heterogeneities: Insights from Three Dimensional Laboratory Experiments. Tectonics 36 (3), 420-443. https://doi. org/10.1002/2016TC004447.

Nestola Y., Storti F., Bedogni E., Cavozzi C., 2013. Shape Evolution and Finite Deformation Pattern in Analog Experiments of Lithosphere Necking. Geophysical Research Letters 40 (19), 5052-5057. https://doi.org/10.1002/grl.50978.

Nestola Y., Storti F., Cavozzi C., 2015. Strain Rate-Dependent Lithosphere Rifting and Necking Architectures in Analog Experiments. Journal of Geophysical Research: Solid Earth 120 (1), 584-594. https://doi.org/10.1002/2014JB011623.

Sandwell D., Muller D., Smith W., Garcia E., Francis R., 2014. New Global Marine Gravity Model from Cryosat-2 and Jason-1 Reveals Buried Tectonic Structure. Science 346 (6205), 6567. https://doi.org/10.1126/science.1258213.

Seminskii K.Zh., Kogut E.I., 2009. Governing Factors in the Development of Depressions and Faults in the Baikal Rift Zone: Results of a Physical Experiment. Doklady Earth Sciences 424 (1), 15-18. http://dx.doi.org/10.1134/S102 $8334 X 09010048$.

Seminsky K.Zh., 2012. Internal Structure of Fault Zones: Spatial and Temporal Evolution Studies on Clay Models. Geodynamics \& Tectonophysics 3 (3), 183-194 (in Russian) [Ceминский К.Ж. Внутренняя структура разломных зон: пространственно-временная эволюция на основе результатов физического моделирования // Геодинамика и тектонофизика. 2012. Т. 3. №. 3. С. 183-194]. https:// doi.org/10.5800/GT-2012-3-3-0070.

Shemenda A.I., 1983. Criteria of Similarity in Physical Modeling of Geodynamic Processes. Geology and Geophysics 10,10-19 (in Russian) [Шеменда А.И. Критерии подобия при механическом моделировании тектонических процессов // Геология и геофизика. 1983. №. 10. С. 10-19].

Shemenda A.I. 1984. Some Regularities of Lithosphere Deformation under Tension. Doklady Earth Sciences SSSR 275 (2), 346-349 (in Russian) [Шеменда А.И. Некоторые аспекты деформаций литосферы при растяжении //Доклады АН СССР. 1984. Т. 275. №. 2. С. 346-349].

Shemenda A.I., Grokholsky A.L., 1991. A Formation and Evolution of Overlapping Spreading Centers (Constrained on the Basis of Physical Modeling). Tectonophysics 199
(2-4), 389-404. https://doi.org/10.1016/0040-1951(91) 90180-Z.

Shemenda A.I., Grocholsky A.L., 1994. Physical Modeling of Slow Seafloor Spreading. Journal of Geophysical Research: Solid Earth 99 (B5), 9137-9153.

Sherman S.I., Bornyakov S.A., Buddo V.Yu., 1983. Areas of Dynamic Influence of Faults (Modelling Results). Nauka, Novosibirsk, 112 p. (in Russian) [Шерман С.И., Борняков С.А., Буддо В.Ю. Области динамического влияния разломов (результаты моделирования). Новосибирск: Наука, 1983. 112 с.].

Sherman S.I., Seminsky K.Zh., Bornyakov S.A., Adamovich A.N., Lobatskaya R.M., Lysak S.V., Levi K.G., 1992. Faulting in the Lithosphere. Extension Zones. Nauka, Novosibirsk, 227 p. (in Russian) [Шерман С.И., Семинский К.Ж., Борняков С.А., Адамович А.Н., Лобацкая Р.М., Лысак С.В., Леви К.Г. Разломообразование в литосфере: Зоны растяжения. Новосибирск: Наука, 1992. 227 с.].

Smith W., Sandwell D., 1997. Global Sea Floor Topography from Satellite Altimetry and Ship Depth Soundings. Science 277 (5334), 1956-1962. https://doi.org/10.1126/science. 277.5334.1956.

Sokoutis D., Corti G., Bonini M., Brun J.-P., Cloetingh S., Mauduit T., Manetti P., 2007. Modelling the Extension of Heterogeneous Hot Lithosphere. Tectonophysics 444 (1-4), 63-79. https://doi.org/10.1016/j.tecto.2007.08.012.

Tentler T., 2003. Analogue Modeling of Overlapping Spreading Centers: Insight into Their Propagation and Coalescence. Tectonophysics 376 (1-2), 99-115. https://doi. org/10.1016/j.tecto.2003.08.011.

Tentler T., 2007. Focused and Diffuse Extension in Controls of Ocean Ridge Segmentation in Analogue Models. Tectonics 26 (50), TC5008. https://doi.org/10.1029/2006TC002038.

Tentler T., Acocella V., 2010. How Does the Initial Configuration of Oceanic Ridge Segments Affect Their Interaction? Insights from Analogue Models. Journal of Geophysical Research: Solid Earth 115 (B1), B01401. https://doi.org/10. 1029/2008JB006269.

The GEBCO_08 Grid, 2009. Version 20090202. The General Bathymetric Chart of the Oceans (GEBCO). Available from: http://www.gebco.net.

Tirel C., Brun J.-P, Sokoutis D., 2006. Extension of Thickened and Hot Lithospheres: Inferences from Laboratory Modeling. Tectonics 25 (1), TC1005. https://doi.org/10. 1029/2005TC001804.

Weatherall P., Marks K.M., Jakobsson M., Schmitt Th., Tani Sh., Arndt J.E., Rovere M., Chayes D., Ferrini V., Wigley R., 2015. A New Digital Bathymetric Model of the World's Oceans. Earth and Space. Science 2 (8), 331-345. https://doi.org/ 10.1002/2015EA000107.

Withjack M., Jamison W., 1986. Deformation Produced by Oblique Rifting. Tectonophysics 126 (2-4), 99-124. https:// doi.org/10.1016/0040-1951(86)90222-2.

Zwaan F., Schreurs G., Naliboff J., Buiter S.H., 2016. Insights into the Effects of Oblique Extension on Continental Rift Interaction from 3D Analogue and Numerical Models. Tectonophysics 693 (B), 239-260 https://doi.org/10.1016/j.tecto. 2016.02.036. 